\title{
Lei e ordem no segundo governo FHC
}

\section{Sérgio Adorno}

\section{As heranças do primeiro mandato}

$\mathrm{N}$ o segundo mandato do governo $\mathrm{FHC}$, não houve mudanças no pla no traçado durante a campanha presidencial, em 1994, tal como publicado em M ãos à 0 bra (cf. C ardoso, 1994). 0 mesmo diagnóstico das causas do crescimento doscrimes ${ }^{1}$ e da violência ${ }^{2}$ permaneceu como pano de fundo das políticas governamentais para o setor. Para além das cau sas macroestruturais relacionadas às injustiças sociais, reconhecidas como obstáculos à promoção de uma sociedade internamente pacificada e fundada na promoção dos direitos humanos, o diagnóstico acentuava a crise do sistema de justiça criminal. I dentificava um elenco de carências institucionais nos mais distintos níveis do Executivo federal - em especial nas muitas esferas de intervenção da polícia federal e da admini stração penitenciária - , como também na esfera dos poderes Judiciário e Legislativo. Ancoradas em um modelo envelhecido de segurança pública, fundado em legislação penal e processual penal ultrapassadas, as agências federais que compõem o sistema de justiça criminal nacional se revelavam incapazes de fazer face ao rápido crescimento dos crimes, em especial dos crimes violentos conectados às modalidades de criminalidade organizada, a par da disseminação quase em cadeia de formas de violência nas relações intersubjetivas, contribuindo para exacerbar sentimentos coletivos de medo e insegurança. Esse diag-

1. C rime é um conceito jurídico que diz respeito à violência codificada nas leis penais. Sabe-se, porém, que nem todo fenômeno, socialmente percebido como violento é categorizado como crime. Do mesmo modo, há modalidades de violência que, emboracodificadas como crime, não encontram adequado enquadramento na legislação penal correspondente. Por exemplo, graves viola ções de direitoshuma- 
nos não raro são enquadradas como crime comum.

2. $R$ ecorro aqui ao conceito sociológico de violência. Segundo Zaluar, "violência vem do latim violentia que remete a vis (força, vigor, emprego de força física ou os reaursos do corpo para exercer sua força vital). Essa força tornase violência quando ultrapassa um limite ou perturba acordos tácitos e regras que ordenam relações, adquirindo carga negativa ou maléfica. É, portanto, a percepção do limite e da perturbação (e do sofrimento que provoca) que vai caracterizar 0 ato como violento, percepção essa que variacultural e his toricamente" (1999, p. 28). nóstico não mudou, a despeito dos fatos novos que vieram se sucedendo ao longo do segundo mandato de $\mathrm{FHC}$, inclusive 0 de maior impacto, entre todos eles, 0 ataque às torres gêmeas do Word Trade C enter, em $\mathrm{N}$ ovaYork, em 11 de setembro de 2001.

Do mesmo modo, o plano geral de ação também não conheceu mudanças substantivas em sua orientação quer política quer pragmática. A o que tudo parece indicar, o governo FH C estava convencido de que, no domínio da segurança pública - como praticamente em todos os domínios de intervenção governamental -, as mudanças seriam lentas e seus resultados colhidos em largo espaço de tempo, certamente não antes do término do segundo mandato. Por certo, reconhecia que, nesse domínio da intervenção governamental, os desafios à mudança não eram apenas de grande magnitude; mais do que isso, os agentes e as agências encarregadas de implementar lei e ordem e de garantir a segurança pública revelavam renitente capacidade de resistir às mudanças institucionais. As rupturas manifestavam-se aqui mais difíceis de serem asseguradas. Poderosos interesses incrustados na burocracia estatal, al guns advindos do regime autoritário, ainda ocupavam um espaço importante nos processos decisórios. O s governos civis que se seguiram ao fim da ditadura pouco se esmera ram no sentido de fomentar um novo quadro de funcionários, civis e militares, mais afinados com as demandas por segurança pública no contexto do Estado D emocrático de Direito.

Por certo, esse julgamento fez com que o governo FHC, no final do seu primeiro mandato, não alterasse sua diretriz geral desenhada para 0 segundo mandato, qual seja, ampliar e melhorar a capacidade das agências governamentais de aplicar lei e ordem, ampliar a proteção dos direitos humanos para o conjunto dos brasileiros e exercer controle mais eficaz sobre o crime organizado, em especial das atividades do narcotráfico em suas conexões com as rotas internacionais e com os centros de produção e de distribuição de drogas.

\section{Os constrangimentos sociaise políticos}

Durante a vigência do segundo mandato do governo FHC, os constrangimentos sociais e político-institucionais que limitaram o alcance dos planos governamentais para a área de segurança, no primeiro mandato, não foram distintos em sua essência. Pelo menos, os grandes marcos estruturais permaneceram atuantes, ora com maior intensidade, ora com menor. 
Por isso mesmo o governo $\mathrm{FH} \mathrm{C}$, em seu segundo mandato, não enfrentou rigorosamente um terreno desconhecido. É certo, porém, que em alguns momentos o cenário parece ter se agravado, ensejando medidas de maior alcance e efeito. As pressões da opinião pública estiveram sempre fortes e reclamando maior presença do governo federal na resolução de problemas relacionados à aplicação da lei e da ordem. Em não poucas oportunidades, o chefe do poder Executivo teve de manifestar-se acerca de problemas de segurança pública que, via de regra, apenas ocupam a atenção de secretários nacionais ou, nos quadros mais graves, ensejam 0 pronunciamento do ministro da Justiça.

$\mathrm{N}$ esse quadro, as sondagens de opinião prosseguiram indicando a violência e a insegurança como al gumas das principais preocupações dos cidadãos brasileiros, ao lado de outros problemas socialmente relevantes, como 0 desemprego e o restrito acesso à escola, à saúde e à habitação. Segundo um levantamento realizado pelo D ataF olha, entre 1996 e 2000, a preocupação dos brasileiros com segurança foi crescente, alcançando seu maior percentual (13\%) no mês de junho de 2000. No ano seguinte, em 2001, um ano apóso anúncio do I Plano N acional de Segurança Pública (PN SP), verificaram- se quedas nesses percentuais. $\mathrm{N}$ o entanto, ao final desse ano e ao longo de 2002, os percentuais voltaram a crescer, possivelmente impulsionados por graves crimes de repercussão nacional que abalaram a opinião pública. Se, por um lado, essas sondagens refletiam tendências reais de crescimento dos crimes e da violência, por outro, deve-se reconhecer que parte da mídia eletrônica e impressa em muito contribuiu para dar forma aos sentimentos coletivos de medo e insegurança com seus relatos cotidianos, folhetinescos, de crimes espetaculares e cada vez mais violentos. $\mathrm{N}$ a mesma direção, parte da mídia, mais conseqüente de suas responsabilidades públicas, amplificou o debate público, encenando debates, mesas- redondas e a escuta freqüente dos mais variados especialistas. M as havia fatos novos também. U m estudo realizado por C ardia (1999) revelava que, contrariamente ao que havia sido observado no início dos anos de 1990, já era possível detectar mudanças no comportamento coletivo em face dos direitos humanos. As tradicionais desconfianças que rela cionavam direitos humanos como "direito de bandidos" pareciam ter sido abaladas. Para alguns segmentos da população, direitos humanos contemplavam direitos sociais, particularmente 0 direito ao trabalho e a todos os demais que asseguram uma vida digna. $N$ ão obstante, a segurança pública persistia como uma questão adstrita à responsabilidade individual.Traba
3. Para maiores informações, ver $D$ ataF olha, Segurança Pública, 10/ 3/ 2002, disponível em www1.folhauol.com.br/ 
4. A despeito desses avanços, os dados coligidos pela Secretaria $N$ acional de Segurança Pública (Senasp), M inistério da Justiça, carecem de confiabilidade. Basta comparar os dados de homicídios divulgados pelo $D$ atasus (Brasil, M inistério da Saúde, 1991-2000) com os da Senasp para atestar enormes distorções. Embora osdados do M inistério da Saúde não estejam isentos de reparos, como têm mostrado vários estudos e, particularmente, M ello Jorge (1997), eles revelam maior confiabilidade e têm sido empregados, com maior freqüência, para efeitos de comparações internacionais.
Ihadores honestos e obedientes às leis teriam direito à segurança; para os criminosos, lei e ordem.

O s crimes e a violência continuaram em níveis elevados. $\mathrm{N}$ ão havia, até fins da década de 1990, estatísticas oficiais de criminalidade para o país em seu conjunto ${ }^{4}$. Essa lacuna começou a ser suprida senão recentemente. O s dados disponíveis, para os anos de 1999 a 2001, divulgados pela Senasp, revelam que, relativamente ao país como um todo, as taxas de crimes violentos por cem mil habitantes - homicídio, roubo, roubo seguido de morte, extorsão mediante seqüestro, tráfico de droga, estupro são, grosso modo, superiores a de outros países com características de organização social comparáveis às do Brasil, conforme Figura 1.

FIGURA 1

Porcentagem de C asos E x ternos de M orte em Países S elecionados dasA méricas (1996-1999)

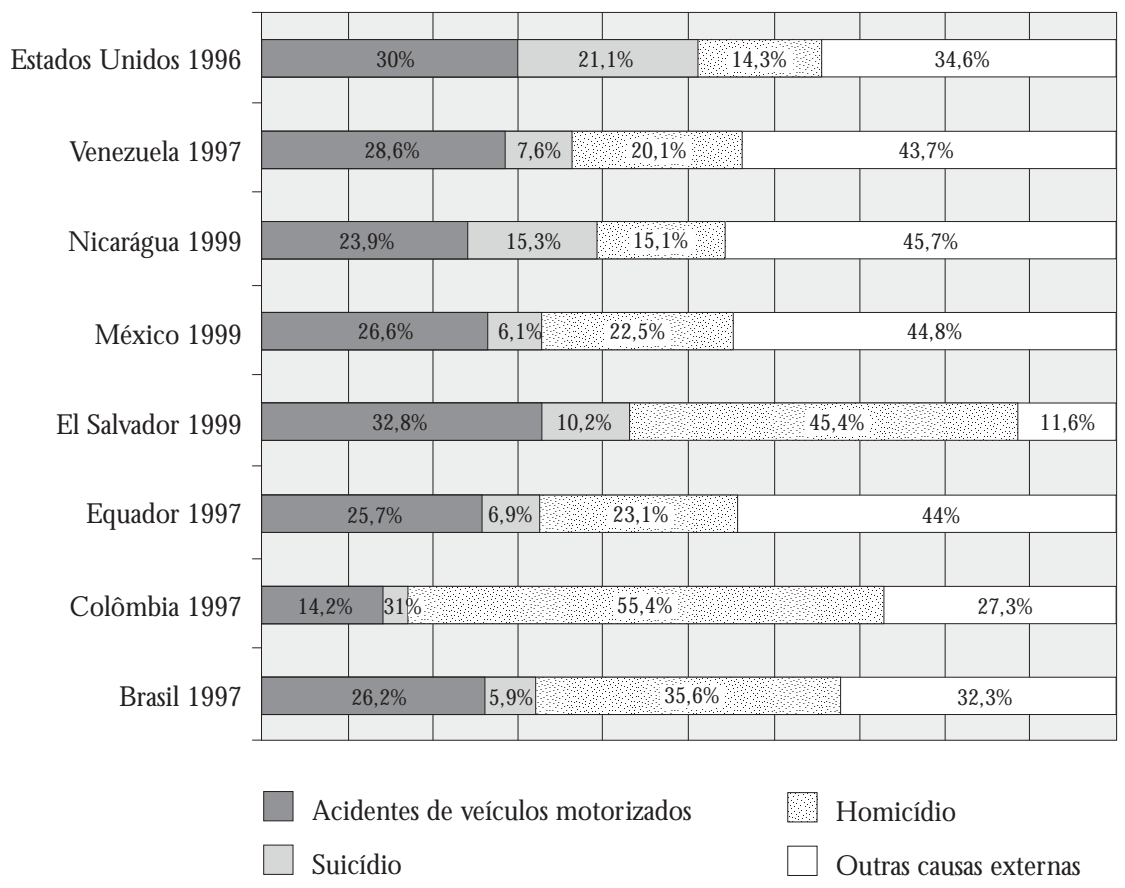

F onte: $O$ rganização Panamericana de Saúde (Paho). D isponível em www.paho.org.

Entre as causas de mortalidade externa, os homicídios correspondem à primeira causa na C olômbia (55,4\%), em El Salvador $(45,4 \%)$ e Brasil (35,6\%). C onvém lembrar que a C olômbia encontra se em guerra civil 
há quase três décadas, ao que se soma o peso do narcotráfico na composição das elevadas taxas de mortalidade intencional. D e modo semelhante, El Salvador, que viveu uma guerra civil, só retomou o Estado de Direito há dez anos. Esses não são os cenários dominantes no Brasil. A qui permanecem focos de conflito, sobretudo relacionados à violência policial e a embates entre bandos de adolescentes e jovens com desfechos fatais, e não há consenso entre os estudiosos a respeito das causas que expliquem o predomínio dos homicídios sobre as demais modalidades de morte por causas externas. C ertamente, é uma composição de causas, para a qual 0 narcotráfico certamente desempenha um papel de destaque, como têm demonstrado muitos estudos de Zaluar (cf., entre outros, Zaluar, 1999). Convém ainda observar que a proporção de homicídios, no Brasil, é mais do que o dobro dos Estados U nidos, país reconhecidamente violento. Em termos ainda de comparações internacionais, a taxa brasileira (26,70 homicídios por 100 mil habitantes, em 2000) foi pouco menor do que a média esperada para países com renda baixa e média, cuja taxa, no mesmo ano, foi de 32,1 homicídios por 100 mil habitantes, o dobro da média para países com renda alta (14,4 homicídios para cada 100 mil habitantes) (cf. O M S, 2002). N o entanto, o B rasil estava em primeiro lugar, em 1999, no ranking de mortes por homicídios de jovens entre 15 a 24 anos, com taxas de 86,7 e 6,5 por 100 mil habitantes, respectivamente para os sexos masculino e feminino; taxas essas acima do que o dobro para países como M éxico e R ússia (cf. Panamerican $\mathrm{H}$ ealth $\mathrm{O}$ rganization - Paho).

0 cenário interno é ainda mais grave, conforme sugere a Figura 2. Saltam aos olhos os dados estatísticos relativos aos homicídios com armas de fogo, com vítimas do sexo masculino, ocorridosnasgrandes capitais brasileiras, particularmente R ecife, C uiabá,V itória, R io de Janeiro, São Paulo, Porto Velho, entre outras, cujas taxas são muito superiores à taxa para o Brasil (34,47 homicídios por cem mil habitantes). Durante o período de 1991 a 2000, essa taxa aumentou 72,58\% (excluídos os homicídios com armas de fogo, ela foi três vezes menor, isto é, aumentou 27,53\%). Essa tendência foi crescente ao longo da década ${ }^{5}$, não estancando nos seus anos finais (19982000), período que coincide com o segundo mandato FH C.

A escal ada da violência e do crime urbanos, desde meados dos anos de 1970, não é, como talvez se pudesse supor, um fenômeno restrito às grandes metrópoles brasileiras, como São Paulo e R io de Janeiro ${ }^{6}$. Cidades de porte médio, com população de mais de 500 mil habitantes, também vêm conhecendo um acentuado crescimento da criminalidade violenta. A in-
5. Essa tendência se repete, com maior ou menor intensidade, nas respectivas regiões metropolitanas. Aliás, no final da década pas sada, 0 enfrentamento das questões de lei e ordem começou a ser abordado no contexto da metropolização explosiva das capitais dos estados. N ão sem razão, ampliaram-se as bases de dados sociais bem como surgiram iniciativas para enfrentamento articulado dos problemas propostos pelo crescimento dos crimes e da violência, como o Fórum M etropolitano de São Paulo, reunindo, em torno do Instituto São Paulo contra aV iolência, 38 municípios que compõem a Região $\mathrm{Me}$ tropolitana (cf. C ardia et al., 2003).

6. A análise que se segue é parcialmente extraída e modificada de Adorno e Cardia(2002). 
teriorização do crime violento vem sendo observada com maior intensidade desde o início da década de 1990, em vários estados brasileiros, como São Paulo, Paraná e M ato Grosso. Ao que tudo indica, a rota do crime urbano segue na esteira da rota da riqueza. C omo se sabe, na década passada, verificou-se grande expansão da riqueza, pública e privada, para o interior do país, como jamais se observara antes.

FIGURA 2

$\mathrm{C}$ oeficiente de $\mathrm{M}$ ortalidade por $\mathrm{H}$ omiádios por $\mathrm{A}$ rmas de $\mathrm{F}$ ogo,

População M asculina, B rasil e C apitais (2000)

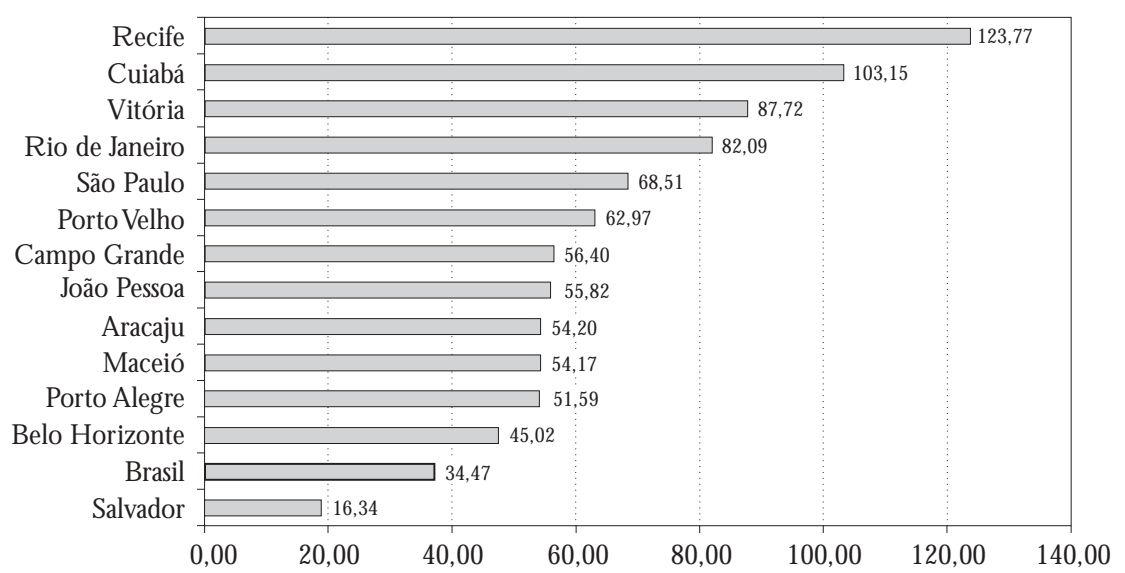

F onte: SU S - M inistério da Saúde, Governo Federal (apud Peres, 2003).

0 rápido acúmulo de capital vem provocando, em curto espaço de tempo, mudanças em múltiplas direções no perfil, em especial, das cidades-sede de regiões estaduais, afetando a infra-estrutura urbana em decorrência dos investimentos em obras públicas e construção civil, o que tem dinamizado o comércio local, os negócios imobiliários e promovido a expansão de serviços que se valem das novas tecnologias de informática e de telecomunicações, sobretudo nos centros urbanos mais avançados. A demais, a construção de modernas rotas viárias ligando os estados e al guns destes com outros países facilita não apenas a circulação intensa, sem controles eficazes, de mercadorias das mais distintas procedências, ao mesmo tempo que estimula contatos mais freqüentes entre estranhos e estrangeiros, gerando imprevistos problemas de lei e ordem. Tais problemas advêm igualmente de mudanças ocorridas na composição social da população, provocadas, por um lado, pela oferta de força de trabalho dos 
municípios circunvizinhos, de outras regiões administrativas do estado ou ainda de outros estados`; e, por outro, pela rápida diversificação da estrutura social local com a expansão, em espaço menor do que uma geração, da escolarização média e superior e, conseqüentemente, da profissionalização de expressivos segmentos da população. Sinais desses temposé o crescimento do ensino superior nessas regiões, estimulado por fundações e organizações privadas, como também o aparecimento de um mercado consumidor muito assemelhado ao das grandes metrópoles.

M uito rapidamente, essas cidades vão se despindo do tradicional perfil das cidades médias interioranas, anteriormente marcado por uma estrutura social quase linear: uma pequena elite local, que controlava os negócios, a propriedade da terra e a política; e um pequeno segmento de classe média, representada por pequenos empresários, comerciantes, profissionais liberais e funcionários públicos, aos quais vêm se associar amplas massas de trabalhadores do campo, das indústrias locais e dos parcos serviços urbanos. Esse não é certamente maiso cenário que caracteriza os municípios recém-enriquecidos do interior. A expansão das classes médias altera esse cenário, sobretudo porque elas passam a dispor de maior representação no mercado, na vida social, pública e privada, e na vida política. N ão sem motivos, é flagrante o fortalecimento das organizações não- governamentais (que perdem sua antiga fisionomia filantrópica), dos movimentos de defesa de direitos civis e dos partidos políticos modernos, menos dependentes dos interesses das antigas classes proprietárias locais.

Essas novas ten dências da urbanização e da metropolização das capitais produzem inúmeras conseqüências que agravam o ciclo crescente da violência. Com a diversificação da estrutura social, da composição social das populações interioranas, transformam-se os estilos de vida, os gostos, as exigências de consumo. D iversificam- se os contatos interpessoais e aumenta a mobilidade das populações, inclusive para fora do país. A melhoria dos sistemas de comunicação, de transporte público e da mal ha viária tem contribuído decisivamente para isso. M as, paral elamente a esses avançose conquistas, desenvolveram- se bolsões de pobreza, alguns encravados no centro urbano decadente, outros sitiados em bairros de classe média, renovados em virtude da expansão dos negócios imobiliários e outros empurrados para a periferia das cidades, onde a precariedade dos serviços urbanos caminha pari passu à baixa oferta de trabal ho, aos baixos graus de escolarização, à falta de atendimento aos grandes segmentos de crianças, adolescentes e famílias jovens recém-constituídas. $N$ esses bolsões, a população não ape- 
8. H á estudos (cf. Pero, 2003, eA ndrade, 1997) apontando fortes tendências ao bloqueio da mobilidade social entre estratos socioeconômicos, entre meados da década de 1980 ea primeira metade da década de 1990, pelo menosnasgrandesregiões metropolitanas. É bem provável que tal fenômeno tenha exercido importante influência não apenas no crescimento daviolênciaedos crimes, mas sobretudo nasformascadavez mais cruéis que vêm caracterizando tais eventosna sociedade brasileira.

9.0 perfil dacriminalidade vem se alterando. Há cerca de uma década era comum haver certa territorialidade da criminalidade; ao menos na região metropolitana, os delinqüentes atuavam em áreascircunscritas $\mathrm{H}$ oje, algunsgruposcriminosos ultrapassam os limites municipais, metropolitanosou asfronteiras estaduais (e até internacionais). nas é sequiosa por trabalho, por acesso às agências promotoras de bemestar e às instituições encarregadas de distribuição de justiça, mas também é mais exposta a situações de risco, como participação em conflitos com desfechos violentos, envolvimento com a delinqüência e ainda é alvo da violência institucional, em suas múltiplas formas, inclusive da violência praticada por agentes policiais nas suas tarefas de controle social ${ }^{8}$.

Esse é, sem dúvida, um contexto bastante favorável para a expansão do crime organizado, em especial do narcotráfico, no interior enriquecido dos estados de M ato G rosso, Paraná e São Paulo.Trata-se, certamente, de um efeito "contaminador" representado, por exemplo, pela proximidade da região de Campinas com a região metropolitana de São Paulo, ou ainda a localização estratégica de cidades como Londrina, no Paraná, e C uiabá, no M ato G rosso, a segunda capital mais violenta do país, no ano de 2000, provocando mudanças nas ações de delinqüentes ${ }^{9}$. E sses aspectos podem estar potencializando os efeitos dos déficits sociais existentes na região, sinalizando para a ausência de redes de proteção social que poderiam prevenir a violência.

C omo se sabe, o tráfico de drogas necessita de um mercado consumidor em emergência, à busca de novas experiências sociais e que disponha de meios suficientes para aquisição regular de drogas, quaisquer que sejam. A demais, necessita de cidadãos empobrecidos, sem trabalho ou sem perspectiva de futuro definido, para agirem como trabal hadores assalaria dos nas diversas atividades previstas na divisão social do trabalho, entre as quais as de controle da distribuição de drogas, do ponto de vendas, da circulação de dinheiro, das dívidas contraídas quer por consumidores quer por pequenos vendedores. Com isso, é alimentada a rede de negócios ilícitos, para a qual concorrem pequenos ou médios comerciantes e empresários, alocados nos mais distintos segmentos do mercado, em especial naqueles de interesse do poder público, como transportes, limpeza, iluminação, abastecimento de água e rede de esgotamento e fornecimento de merenda escolar. I nstalam-se conluios entre o poder público e o mercado, cujo saldo converge para fins como financiamento de campanhas eleitorais e a manutenção de um amplo segmento de lobistas, intermediários entre negócios e profissionais encarregados de exercer influência política sobre aqueles incumbidos de tomar decisões que implicam dispêndio de recursos públicos. $\mathrm{N}$ ão é preciso dizer que esse é também um contexto muito favorável à explosão de conflitos entre grupos políticos e sociais portadores de interesses convergentes, porém em permanente competi- 
ção. N ão raro, também, esses conflitos tendem a ser resolvidos pelo emprego da força física, o que remete ao concurso de pistoleiros profissionais, freqüentemente recrutados no interior do crime organizado e mesmo entre segmentos corrompidos do aparelho policial ${ }^{10}$.

Por fim, as mudanças so ciais em curso que afetam o controle público da ordem social não foram acompanhadas de mudanças radicais no sistema de justiça criminal, em todosos seus segmentos: aparelho policial, aparel ho judicial e sistema penitenciário. 0 crime cresceu e mudou de qualidade; porém, o sistema de justiça permaneceu operando como o fazia há três ou quatro décadas. Em outras palavras, aumentou sobremodo o fosso entre a evolução da criminalidade e da violência e a capacidade do Estado de impor lei e ordem. 0 ssintomas mais visíveis desse cenário são as dificulda des e os desafios enfrentados pelo poder público em suas tarefas constitucionais de deter o monopólio estatal da violência, sintomas representados pela sucessão de rebeliões nas prisões, ocorridas, em grande parte, sob a coordenação de dirigentes do crime organizado, como o Comando Vermelho e o Terceiro Comando, no R io de Janeiro, e o Primeiro Comando da C apital (PCC ), em São Paulo, este responsável pelo motim simultâneo de 29 grandes prisões, no estado de São Paulo, em janeiro de 2001. Do mesmo modo, cada vez mais é flagrante a ousadia no resgate de presos, a existência de áreas das grandes cidades onde prevalecem as regras ditadas, por exemplo, pelo tráfico de drogas em detrimento da aplicação das leis.

$\mathrm{N}$ ão sem motivos, o segundo mandato do governo $\mathrm{FHC}$ não conheceu, novamente, dias de tranqüilidade. D urante esse período, ocorreu uma sucessão, por todo o país, de graves eventos de violência e de crime, muitos dos quais com requintes de crueldade antes desconhecidos. Para lembrar os de maior impacto: a absolvição dos PM s envolvidos na morte de dezenove sem-terras em Eldorado dos C arajás (PA ), em maio de 1999; 0 evento provocado por serial killer, estudante de medicina, que disparou tiros com uma arma automática contra os expectadores de uma sala de cinema em um shopping center na cidade de São Paulo, em novembro de 1999; as rebeliões que se sucederam na Fundação do Bem-Estar do M enor (Febem), com a morte de quatro internos, um dos quais com a cabeça decepada e o corpo queimado em uma fogueira, em 2000; 0 seqüestro do ônibus 174, no R io de Janeiro, em junho de 2000, com sua história trágica e repercussão na mídia nacional e internacional; 0 assassinato dos pais, em bairro de alta classe média, em São Paulo, por Suzane Louise von R ichthofen, 19 anos, estudante de direito na PU C/SP, em outubro de
10. Cf. Brasil, Câmara Federal dosD eputados, 2002. A C omissão apurou parte substantiva desses problemase suas conseqüênciasquer sobre asociedade brasileira quer sobre o sistema de justiça criminal. 
11. Tudo indica ter se tratado de uma operação conjunta de policiaismilitares do Grupo de Repressão e Análise dos $D$ elitos de Intolerância (Gradi), do Comando de Policiamento de $\mathrm{C}$ hoque (C PChq) e do Tático O stensivo R odoviário (TO R ), do I Batal hão da Polícia R odoviária de São Bernardo do Campo (BPR v). Igualmente, há indicações da participação de policiais civis do Grupo de 0 perações Policiais (GOE) e do Grupo Armado de R epressão a R oubos e Assaltos (Garra).
2001; a execução de doze acusados de integrar a facção criminosa PCC, em operação armada por serviços de inteligência policiai $s^{11}$ na rodovia C astelo Branco, no pedágio próximo a Sorocaba, episódio conhecido como C astelinho; a morte do jornalistaT im Lopes, da R ede Globo, como decorrência de suas reportagens sobre o baile funk na favela daV ila C ruzeiro, uma das doze que integram o chamado C omplexo do A lemão, subúrbio do R io de Janeiro, em junho de 2002; e, por fim, a seqüência de confrontos entre o crime organizado e o governo estadual do $\mathrm{R}$ io de Janeiro, durante a gestão da governadora Benedita da Silva (de julho a agosto de 2002), marcada por episódios como o atentado à prefeitura da cidade do $\mathrm{R}$ io de Janeiro, o encontro de bazuca, de fabricação sueca na favela $\mathrm{N}$ ova H olanda, no C omplexo da M aré, em Bonsucesso, além da descoberta de cemitérios clandestinos nos quais eram enterradas pessoas assassinadas pelo tráfico de drogas, tidas como desaparecidas, o que culminou também com a descoberta de que traficantes incineravam corpos dentro de pneus, simbolicamente denominados de "forno de microondas". Evidentemente, nenhum desses fatos é de responsabilidade direta do governo FHC. Porém, o impacto com que repercutiram na mídia eletrônica e na opinião pública sugere que os problemas herdados de gestões anteriores permaneciam intocados e as promessas de campanha restavam por serem efetivamente implementadas. Esse quadro torna- se ainda maiscomplexo quando, lado a lado ao crime comum e organizado, observou-se no período a persistência de graves violações de direitos humanos, bem como uma verdadeira explosão de conflitos nas relações intersubjetivas.

É certo que, a despeito dos problemas, houve, mesmo na gestão anterior, iniciativas de reforma da legislação penal e de reaparelhamento do sistema de justiça criminal, promovidas pelo governo federal e, parcialmente, executadas por governos estaduais.Todavia, estiveram muito aquém das expectativas da população por maior segurança. A lgumas avaliações sugerem mesmo a queda dos investimentos em segurança pública e justiça desde meados da década de 1980. Esses investimentos foram, em sua maior parte, endereçados à aquisição de novos equipamentos, como veículos e armas, e à reforma de instalações. Pouco se fez para a reforma institucional da polícia e das agências que compõem o sistema de justiça criminal, sobretudo o enfrentamento de alguns problemas crônicos como ineficiência operacional, baixa capacidade de resolução de casos, baixo investimento em recursos humanos especializados, em inteligência policial, além dos já tradicionais problemas de corrupção e de violência insti- 
tucional, como a rotineira prática de tortura nas delegacias de polícia. $\mathrm{N}$ esse contexto, intensificam- se as preocupações com o impacto dos custos - diretos e indiretos - da violência sobre vidas, patrimônio pessoal e público, gastos com segurança privada, e o dispêndio de parcela não desprezível do PIB ${ }^{12}$ visando a proteger empresas e a garantir a regularidade da produção.Tudo isso sem contar o impacto sobre o valor de imóveis em áreas residenciais de menores taxas de crimes. 0 que parece de fato ter prosperado nesse período foram as empresas e os serviços de segurança, sobretudo a indústria de blindagem de veículos automotores particulares.

A tudo isto, é necessário acrescentar também certa fragilidade de organização da sociedade civil na defesa de interesses relacionados à segurança pública. 0 baixo desempenho do sistema de justiça criminal se deve, em parte também, à ausência de controles externos, mais propriamente de uma cultura de prestação de contas à sociedade dos planos formulados e implementados para a área de segurança pública, bem como de seus resultados, esperados e alcançados, ao que vem se associar o precário controle interno. Este ainda mais grave quando se trata das polícias militar e civil situadas em estados onde só recentemente foram criadas as ouvidorias de polícia. Essa quase absoluta autonomia do sistema policial, independentemente de quaisquer mecanismos de accountability externo, vem contribuir para reforçar o corporativismo institucional, reconhecidamente um dos obstáculos ao controle da violência institucional nos marcos do Estado de D ireito. Estudo de Lemgruber et al. (2003) sobre o desempenho das ouvidorias de polícia revela que elas estão ainda dando seus passos iniciais, e não têm recebido o apoio necessário quer dos órgãos governamentais, quer da sociedade civil organizada. Importantes outras iniciativas e inovações, como os centros integrados de cidadania (cf. H addad et al., 2003), ainda revelam pouca força tanto para reduzir o medo que a população tem da polícia, como para encorajá la a enfrentar os problemas locais de tráfico de drogas.

Em linhas gerais, essa é uma conjugação de forças e tendências que explicam o crescimento da violência e dos crimes no país, em especial suas novas tendências no sentido da interiorização e da expansão do crime organizado.

\section{O segundo mandato FHC}

A té aqui mostramos o contexto no qual o governo $\mathrm{FHC}$ procurou implementar sua política de segurança no segundo mandato. H erdou pro-
12. As avaliações são ainda bastante imprecisas. $\mathrm{N}$ o entanto, dados divulgados pela Secretaria $\mathrm{N}$ acional de Segurança Pública indicavam que, no município de São Paulo, em 1999, 310 bilhões do PIB referiam-se ao custo estimado do montante da violência e da criminalidade; no município do $\mathrm{R}$ io de Janeiro, em 1995, foram gastos 51 bilhões; $e$, no município de Belo $H$ orizonte, 21 bilhões (C entro de Estudos de C riminalidade e Segurança Pública da U FM G, Instituto Superior de Estudos da R eligião el nstituto La tinoamericano das $\mathrm{Na}$ ções U nidas para Prevenção do D elito eTra tamento do Delinqüente. Cf. www.mj. senasp.gov.br. 
blemas do mandato anterior e teve de enfrentar um país maise mais complexo, em que os problemas acumulados de violência e de crime repercutiram tanto nos sentimentos de insegurança e medo coletivos, como nas desconfianças dos cidadãos em suas instituições encarregadas da lei e da ordem. Para agravar ainda mais esse cenário, o M inistério da Justiça, centro nevrálgico da política de segurança, conheceu nove titulares ao longo da era FHC! A fim de assegurar maioria parlamentar e garantir a aprovação dos projetos de lei de interesse maior do governo, a pasta da Justiça foi freqüentemente moeda de troca entre partidos de apoio do governo, nota damente o PM D B, o que dificultou em larga medida a adoção de políticas mais conseqüentes e mais duradouras. Foi no interior desse quadro, bastante adverso, diga-se de passagem, que o segundo mandato do governo FHC cogitou tornar-se protagonista e reverter a situação encurralada em que se encontrava.

\section{Os direitos humanos}

Logo no início do segundo mandato, o presidente anunciou uma reforma ministerial com o propósito de contemplar demandas por cargos, nascidas dos acordos e das alianças que sustentaram as mudanças constitucionais que asseguraram a reeleição. Escapa aos propósitos deste ensaio examinar as negociações de que foi objeto o $\mathrm{M}$ inistério da Justiça. $\mathrm{O}$ resultado dessas negociações alçou o secretário $\mathrm{N}$ acional de Direitos $\mathrm{H} \mathrm{u}$ manos, José G regori, ao cargo de ministro da Justiça. Para o cargo de secretário foi indicado, após consultas e mesmo pressões políticas em torno de nomes que circulavam como prováveis candidatos, o embaixador Gilberto Sabóia. Embora tenha permanecido poucos meses no cargo, teve sob sua responsabilidade a chefia da missão brasileira na Conferência $M$ undial contra o R acismo, a D iscriminação R acial, a X enofobia e Intolerância Correlata realizada, em 2001, em Durban (África do Sul), reunião que acenava com grandes avanços, sobretudo no que concerne à questão palestina, não fosse a forte pressão contrária dos Estados U nidos e de I srael. 0 governo federal prosseguiu, nesse domínio, anunciando fortes sinais de que estava comprometido com a questão dos direitos humanos e pretendia avançar nas conquistas obtidas no mandato anterior, tanto assim que cuidou para que uma brasileira, Edna R oland, fosse eleita a relatora geral da cúpula.

A despeito de afinado com 0 andamento das tratativas internacionais nessa área, o embaixador Gilberto Sabóia, no entanto, não revelou 0 
protagonismo que o cargo exigia, sobretudo no enfrentamento de graves violações de direitos humanos comprometedoras da imagem do governo brasileiro no exterior, como também não conseguiu articular as demandas dos distintos grupos de ativistas pelo avanço de suas conquistas e reivindicações. Em outubro de 2001, a Secretaria N acional de D ireitos H umanos ${ }^{13}$ passou a ter novo titular: o professor Paulo Sérgio Pinheiro, coordenador do N úcleo de Estudos daV iolência da U SP, titular de ciência política nessa universidade e promotor de direitos humanos reconhecido internacionalmente.

$\mathrm{N}$ o segundo mandato, o governo $\mathrm{FHC}$ continuou na mesma linha de orientação adotada no mandato anterior. Prosseguiu suas tarefas no sentido de implementar os acordos e as convenções internacionais, como as promulgações: pelo D ecreto № 3.331/ 99, do Protocolo A dicional à C onvenção A mericana sobre $D$ ireitos $H$ umanos em matéria de direitos econômicos, sociais e culturais, denominado "Protocolo de São Salvador", concluído em novembro de 1988; pelos D ecreto $n \div 3.413 / 00$ e n 3.951/ 01, da C onvenção sobre os A spectos C ivis do Seqüestro Internacional de C rianças, concluída na cidade de $\mathrm{H}$ aia em outubro de 1980; pelo D ecreto no 3.597/ 00, da Convenção 182 e R ecomendação 190 da O rganização Internacional do Trabalho (OIT) sobre a proibição das piores formas de trabalho infantil e a ação imediata para a sua eliminação, concluídas em Genebra em junho de 1999; pelo Decreto no 4.316/02, do Protocolo Facultativo à C onvenção sobre a eliminação de todas as formas de discriminação contra a mulher, ao mesmo tempo expediu o D ecreto $n$ ㅇ 4.377/ 02 , ratificando essa mesma C onvenção para suspender as antigas restrições e reservas do Decreto no 8.9460/84; pelo D ecreto ำ 4.388/02, do Estatuto de Roma do Tribunal Penal Internacional; e pelo Decreto no 4.463/02, do R econhecimento da Corte Interamericana de Direitos $\mathrm{H}$ umanos em todos os casos de violação de Direitos H umanos previstos no Pacto de São José.

Como se pode verificar, o governo federal buscou tanto ratificar convenções firmadas há, pelo menos, duas décadas que permaneciam pendentes, certamente por reservas procedentes quer da política externa quer dos compromissos que tais políticas ensejam com muita freqüência para os governos estaduais. Ao mesmo tempo, buscou ratificar, de imediato, convenções recém-firmadas, com o nítido propósito de evitar obstáculos que pudessem postergar sua implementação em território nacional. I gualmente, atacou áreas, sempre sensíveis ao debate e às influências políticas,
13. N o segundo mandato FH C, a Secretaria $\mathrm{N}$ acional de Direitos $\mathrm{H}$ umanos ganhou status de Secretaria de Estado e o secretário, 0 de ministro. 
como o trabalho infantil, a adoção internacional de crianças, o abuso e a exploração sexual de crianças e adolescentes, a eliminação das formas de discriminação contra a mulher, a par de temas candentes como o reconhecimento do Tribunal Penal Internacional para Julgamento de Crimes contra a H umanidade e da Corte Interamericana de D ireitos $\mathrm{H}$ umanos para apurar responsabilidade em quaisquer crimes previstos no Pacto de São José, ou o reconhecimento dos direitos humanos contemplando direitos econômicos, sociais e políticos.

A esse conjunto de iniciativas vieram associar-se outras, como a permissão para a visita regular de observadores e relatores especiais para os D ireitos H umanos; 0 diálogo permanente com o Alto Comissariado das $\mathrm{N}$ ações $U$ nidas para os $\mathrm{D}$ ireitos H umanos (ACN U DH ), cujo ápice ocorreu com a visita da al ta comissária, $M$ ary $R$ obinson, que resultou na assinatura de protocolos de cooperação; e a criação de uma Comissão de Tutela dos $D$ ireitos $H$ umanos. Promoveu seminários e encontros regionais com o propósito de estimular cada vez mais a inserção do país nos sistemas internacionais de direitos humanos. Tudo indica, por conseguinte, clara orientação política para mudar a imagem externa do país, freqüentemente veiculada na mídia internacional como uma nação que não apenas tolera e convive com graves violações de direitos humanos, mas cujo governo pouco faz para punir os responsáveis por tais agressões. M udar essa imagem pode significar melhor inserção no cenário político internacional, maior confiança nos organismos de cooperação interna cional e, até mesmo, maior confiança dos investidores externos.

C onsiderando a tradição brasileira na área, podemos ser levados a suspeitar de que tudo isso não passou de retórica governamental. N o entanto, várias dessas iniciativas implicaram a destinação de recursos e a criação de instrumentos e meios de execução de planos e programas de ação. Daí porque foi necessário articular politicamente esses compromissosinternos com as demandas por proteção de direitos procedentes dos distintos grupos discriminados, muitas delas estimuladas pelo I Programa $\mathrm{N}$ acional de D ireitos H umanos (PN D H ), em 1996. Essa articulação foi executada, preferencialmente, por três modalidades de ação governamental:a) criação de conselhos de cidadania; b) parcerias com a sociedade civil organizada; c) programas de atendimento especial a grupos sociais discriminados.

O s conselhos de cidadania já haviam sido criados anteriormente, inclusive mesmo antes do governo $\mathrm{FHC}$, como o Conselho $\mathrm{N}$ acional de D efesa dos D ireitos da C riança e do A dolescente (C onanda), em 1991; 0 
Conselho de Defesa dos Direitos da Pessoa H umana (CDDPH), criado em 1964 e reativado em 1979; 0 C onselho $\mathrm{N}$ acional dos Direitos da M uIher (C N D M ); e o C onselho D eliberativo Federal de Programa de Assistência aV ítimas e Testemunhas A meaçadas, em 1996. D urante o segundo mandato de $\mathrm{FHC}$, foram criados o Conselho $\mathrm{N}$ acional dos Direitos do Idoso, em 2001; a Comissão Especial para acompanhar as denúncias de torturas, no mesmo ano; a C omi ssão Especial para reconhecer e acompanhar denúncias de violência no campo, exploração do trabalho forçado e escravo e do trabalho infantil, em 2002; 0 C onselho $\mathrm{N}$ acional dosD ireitos da Pessoa Portadora de D eficiência (C onade), em 1999; o Conselho N acional de Promoção do Direito à Alimentação (CN PDA), em 2002; 0 Conselho das A utoridades $C$ entrais B rasileiras em $M$ atéria de $A$ doção Internacional, em 1999; e o C onselho $\mathrm{N}$ acional de Combate à D iscriminação que, embora criado em 1998, teve sua composição estabelecida pelo D ecreto $n=3.952 / 2001$.

A maioria desses conselhos não faz parte, rigorosamente, da Secretaria de Estado dos $\mathrm{D}$ ireitos $\mathrm{H}$ umanos, porém, cabe a esta pasta prover os recursos necessários para o funcionamento regular desses órgãos, inclusive assessorá-los em suas atividades admini strativas, como convocação de sessões e realização de reuniões. 0 papel desses conselhos concentra-se em torno de três linhas de ação: a) acompanhar casos de denúncias de graves violações de direitoshumanos; $b$ ) orientar e assessorar a conduta do governo federal diante desses casos e auxiliar nas tarefas propostas pela política de direitos humanos; c) propor medidas para sanar problemas e dotar as políticas de maior eficiência institucional. U ma vez que as comissões e os conselhos reúnem representantes de órgãos governamentais, de organizações não-governamentais, universidades e outras associações da sociedade civil, isso permitiu, de algum modo, arejar as relaçõesentre governo federal e militantes de direitos humanos, bem como aproximar as políticas públicas de seus interlocutores privilegiados na sociedade civil. 0 importante é que, por meio de taisconselhos, foi sendo possível formular e implementar políticas afirmativas voltadas, principalmente, para a proteção de direitos das crianças, das mulheres, dos idosos, dos negros e dos homossexuais.

Certamente, alguns conselhos e comissões funcionaram melhor do que outros. Tradição, experiência acumulada, maior capacidade de interlocução entre pares e governantes contribuíram para que fossem mais atuantes e suas ações ganhassem maior visibilidade e produzissem efeitos de maior impacto. D e modo geral, esses órgãos tiveram papel decisivo no 
14. Em seu relatório de atividades, no final da segunda gestão $\mathrm{FHC}$, a Secretaria de Estado dos $\mathrm{D}$ ireitos $\mathrm{H}$ umanos informava haver gastado $R \$ 12.527 .597,81$ (=U \$4 319 861,31), no período de 13 de maio de 1996 a 8 de novembro de 2002, em projetos em co-parceria com o Programa das $\mathrm{N}$ ações $\mathrm{U}$ nidas para 0 D esenvolvimento (PN U D ), U nited N ations Educational, Scientific and Cultural O rganization (U nesco), $U$ nited $\mathrm{N}$ ations $\mathrm{D}$ evelopment Fund for Women (U nifem), Fundo das $\mathrm{N}$ ações U nidas para a População (FNUAP), para atendimento de criançase adolescentes, acesso à justiça e combate à discriminação, atenção às pessoas portadoras de deficiência, as sistência às vítimase a testemunhas ameaçadas, combate à tortura, combate à violência contra a mulher. Certamente, é difícil ava liar, por ora, o que significa esse valor. Ele representa algo em torno de U $\$ 730.000$ a cadaano, um orçamento apertado se consideradaa magnitude dos problemasa serem en- sentido de pautar a implementação da política de direitos humanos, assim como no trabalho de tornar público, em especial através da mídia, as principais iniciativas do setor.

$\mathrm{N}$ a mesma direção, o governo federal cuidou de dar prosseguimento às parcerias com a sociedade civil, mediante a realização de convênios para execução de projetos. N essa medida, buscou apoio nasuniversidadese em centros de pesquisa, seja para ampliar o conhecimento sobre problemas determinados (como, por exemplo, os estudos realizados pelo $\mathrm{N}$ úcleo de Estudos daV iolência - N EV (USP) e pelo Instituto Superior de Estudos da R eligião - I ser (R J), seja para a intervenção em áreas determinadas, de que resultaram inúmeras publicações na forma de relatórios, textos de recomendação, documentos técnicos, livros e coletâneas. N esse campo, suas principais iniciativas foram a criação do Serviço C ivil Voluntário; o C entro $\mathrm{N}$ acional de Formação C omunitária (C enafoco); os $\mathrm{O}$ bservatórios de D ireitos H umanos (parceria entre N EV, Instituto São Paulo contra aV iolência e Instituto Sou da Paz, todos sediados em São Paulo); políticas de ação afirmativa para afro-descendentes; criação da R ede $\mathrm{N}$ acional de Direitos $\mathrm{H}$ umanos, além de haver proposta a nomeação de $\mathrm{R}$ elatores $\mathrm{N}$ acionais em D ireitos H umanos para osD ireitos E conômicos, Sociaise C ulturais, na esteira do modelo adotado pelo al to comissariado da O N U para os D ireitos H umanos, baseado nas visitas locais e na produção de relatórios. Cabe destacar que as duas primeiras iniciativas não resultaram do I PN D H, mas do I PN SP, de 2000; um esforço, ainda que tímido, de estabelecer conexões mais sólidas entre direitos humanos e segurança pública.

Certamente, parcerias para execução de projetos representaram uma parcela substantiva dos recursos orçamentários ${ }^{14}$, até porque muitos deles envolviam execução de ações previstasno I PN DH . D e acordo com informações fornecidas pela Secretaria de Estado dos D ireitosH umanos, praticamente $1 / 3$ dos recursos esteve concentrado em convênios firmados com órgãos governamentais e não-governamentais sediados nos estados de São Paulo e R io de Janeiro. M inas Gerais, Pernambuco, R io Grande do Sul, Distrito Federal e Bahia responderam por outra parcela de 1/3. 0 restante foi dividido entre os demais estados. À primeira vista, a distribuição de recursos não resulta necessariamente de uma avaliação das regiões onde predominam as graves violações de direitos econômicos, sociais e políticos, porém, parece obedecer a uma outra lógica: a da existência local de grupos com maior capacidade propositiva e de execução de projetos, bem como de maior presença e apelo na mídia nacional. 
Se essa hipótese estiver correta, é possível suspeitar que, ainda no segundo mandato de FHC, problemas relacionadoscom graves violações de direitoscivis- como violência praticada por agentespoliciais, inclusive com vítimas fatais, violência nas instituições de controle e de contenção social, problemas relacionados às crianças e aos adolescentes nas ruas - predominaram sobre a violação de direitos econômicos, sociaise políticos. N ão se trata evidentemente de reconhecer que violação de direitos civis ocorre nas regiões Sul e Sudeste, enquanto violação de direitos econômicos, sociais e políticos predomina nas demais regiões. Em todos os estados da federação, independentemente de região, o rol de graves violações de direitos humanos alcança todos esses direitos. Porém, é forçoso reconhecer, como o demonstram os estudos disponíveis e mesmo os relatórios do Índice de Desenvolvimento Humano (IDH), que as desigualdades socioeconômicas são bem mais acentuadas nos estados do $\mathrm{N}$ ordeste e do $\mathrm{N}$ orte do país. N esse sentido, se o propósito do governo FH C, em seu segundo mandato, era o de atacar com maior envergadura as graves violações de direitoseconômicos, sociai se políticos como uma estratégia para fazer avançar ainda maisa agenda de direitos humanos no Brasil, esse propósito não encontrou guarida na alocação de recursos para implementação de projetos.Tudo indica que, em uma área "tão contemporânea" como a dos direitos humanos, as estratégias políticas dos grupos sociais, militantes dos direitos humanos, não se destacam das tradições políticas brasilei ras, comuns em outras áreas da intervenção governamental. Por certo, se essa orienta ção evita os crônicos problemas de clientelismo que marcam, ainda hoje, a política brasileira, não é menos certo que outras orientações contribuem para reforçar as desigualdades regionais, acentuando o desequilíbrio de poder entre os segmentos da população que demandam políticas sociais cada vez mais universalistas e aqueles que demandam políticas particularistas. I dentificamos aqui, por conseguinte, um dos limites da política dos direitos humanos que não logrou ser superado ao longo do segundo mandato.

A despeito desse impasse, o PN D H não foi relegado a segundo plano, mesmo porque a maior parte desses projetos e convênios visaram a atender metas e prioridades nele estabelecidas. N o segundo mandado de seu governo, o presidente FHC pretendeu superar algumas críticas que haviam sido endereçadasao I PN DH ,em particular o silêncio em relação aos direitos econômicos, sociaise culturais, além do esquecimento em face de al gumas demandas de grupos específicos, como a proteção e a defesa dos direitos de homossexuais, idosos, pessoas portadoras de deficiência e indí- frentados. De qualquer forma, indica mobilização governamental no sentido de enraizar uma tradição de políticas para esta área da vida social. 
genas, que haviam merecido pouca atenção no mandato anterior.Tendo sido avaliado em seus primeiros anos de implementação, o "I R elatório N acional sobre os Direitos H umanosno Brasil" (cf. Pinheiro, 1999) identificou as principais lacunas e os problemas que necessitavam ser atacados com prioridade.

A colhendo conclusão alcançada na IV C onferência $\mathrm{N}$ acional dos Direitos $\mathrm{H}$ umanos, realizada na $\mathrm{C}$ âmara dos $\mathrm{D}$ eputados, em B raślia, nos dias 13 e 14 de maio de 1999, o governo federal procedeu à revisão do I PN DH e editou o II Programa N acional de Direitos Humanos (2000) com o propósito de incorporar os direitos econômicos, sociais e culturais. O II PN D H manteve as grandeslinhas de orientação contidasno anterior, todavia acolheu ações específicas quanto à garantia do direito à educação, à saúde, à previdência e assistência social, ao trabalho, à moradia, ao meio ambiente saudável, à al imentação, à cultura e ao lazer. Previu campanhas de sensibilização da sociedade brasileira para com a cultura dos direitos humanos.A colheu também o desejo por mai or e melhor monitoramento das ações implementadas. Buscou assegurar dotação de recursos próprios para esse fim nos orçamentos federal, estadual e municipal.T ransformada essa exigência em ato normativo, o governo federal dispôs de recursos orçamentários, destinados ao II PN DH , no Plano Plurianual (PPA) de 20022003. No entanto, no ano de 2002, a implementação do II PN D H identificou, do total de 153 ações previstas, a existência de 72 programas governamentais, em distintos setores da administração direta federal, que, de al gum modo, atendiam aos objetivos pretendidos. Disso resultou a ava liação de que

[...] não faz sentido alocar recursos para implementação do PN DH , sendo que estes recursos já existem e já são investidos em programas cujos resultados têm impacto direto sobre a garantia dos direitos humanos. Torna-se prioritário, portanto, estabelecer mecanismos de monitoramento da atividade governamental, em nível federal, estadual e municipal, com o objetivo de garantir sua eficácia, eficiência e efetividade em termos da garantia de direitos (Brasil, SEDH , 2002, p. 41).

Ainda que se possa objetar que essa orientação tenha sido correta do ponto de vista da racionalização dos recursos e da maior especialização da Secretaria de Estado dos Direitos H umanos no sentido de promover 0 monitoramento da aplicação desses direitos, não há como deixar de reconhecer seus limites. C omo se sabe, não foram poucas as críticas endereçadas 
às políticas sociais do perío do $\mathrm{FHC}$, certamente um dos fatores que contribuíram para que o candidato do governo $\mathrm{FHC}$ à eleição presidencial de 2002 acabasse derrotado. Além dos tradicionais obstáculos burocráticos que dificultam a chegada dos recursos ao destinatário final, a fragmentação das políticas sociais em distintos ministérios e órgãos da administração direta e indireta é reconhecidamente uma estratégia de gestão político-administrativa que reforça os poderes locaise as áreas de influência de grupos políticos e corporações, inclusive seus segmentos de mercado que prestam serviços ao governo. Portanto, não era de esperar que essa orientação viesse contemplar, de fato, os direitos econômicos, sociais e culturais expandidos no II PNDH.

$\mathrm{N}$ o final do segundo mandato de FHC, esse PNDH foi novamente avaliado, resultando no "II R elatório $\mathrm{N}$ acional sobre osD ireitos $\mathrm{H}$ umanos no B rasil". M ais completo do que o anterior, esse documento reconhecia avanços no campo dos direitos humanos, por força quer das ações governamentaisquer das iniciativas da so ciedade civil organizada. N ão obstante, apontava para a persistência de graves desigualdades regionais e sociais entre classes sociais que comprometiam a qualidade da vida democrática e mesmo a integridade do Estado de D ireito. Em parte, o documento parece indicar, comparativamente ao anterior, maior extensão de problemas. A o lado das graves violações relacionadas com o direito das mulheres, das crianças e dos ado lescentes, das po pulações afro- descendentes, dos indígenas, verifica se maior acuidade para problemas relacionadoscom violência rural e trabal ho escravo, portadores de deficiência, idosos, migrantes, homossexuais, ciganos, perseguidos políticos, desaparecidos políticos. I gualmente, alargaram- se as preocupações relacionadas com crianças e adolescentes, como a exploração, abuso e turismo sexuais, e trabalho infantil; com afro-descendentes, como a propriedade legal de terras de quilombos e a implementação de políticas afirmativas; com indígenas, como saúde, mortalidade e fome; com as mulheres, como a persistência de discriminação nos Códigos Penal e C ivil. Tudo isso pode sugerir que os problemas cresceram e se multiplicaram a despeito da política de direitos humanos do governo FHC.É possível que assim seja. M as, é igualmente possível que melhoraram osmecanismose osinstrumentos de detecção de problemase denúncias, assim como aumentou a confiabilidade dos cidadãos e cidadãs brasileiras nas instituições encar regadas de promover os direitos humanos. $M$ aior confiabilidade pode se traduzir em menor medo para oferecer denúncia e para relatar os problemas locais, o que em si pode estar revelando, 
ainda que de modo indireto, anteso êxito das políticasadotadas do que seu fracasso e limitações.

\section{Segurança pública}

$\mathrm{O}$ fato de $\mathrm{FHC}$ ter sido reeleito já no primeiro turno parecia tornar favoráveis, em seu segundo mandato, as condições político-institucionais para promover reformas substantivas no domínio da segurança pública, débito herdado do mandato anterior. 0 cenário parecia se agravar à medida que fatos espetaculares, ocorrendo em todas as regiões do país e mais particularmente nas regiões metropolitanas do R io de Janeiro e de São Paulo se sucediam com mai or freqüência, acentuando os sentimentos populares de medo e insegurança. Foi nesse contexto que o ministro José Gregori recebeu a incumbência de preparar um plano de ação que produzisse maior impacto e resultados em curto e médio prazos. R eunindo às suas voltas especialistas, consultores, estudiosos e pesquisadores, além de operadores do sistema de segurança pública mais afinados com os propósitos do governo FHC, o M inistério da Justiça apresentou, no ano de 2000, o Plano N acional de Segurança Pública (PN SP).

O Plano pretendeu alcançar o sistema de segurança pública em seu conjunto, pelo menos no que concernia às áreas de competência do poder Executivo. R ecuperava, portanto, 0 entendimento contido em $M$ ãos à 0 bra (cf. C ardoso, 1994), que propunha uma abordagem sistêmica e holística para o enfrentamento dos graves problemas de segurança pública no país. A própria estrutura do documento é ilustrativa dessa característica. Primeiramente, organiza as áreas de intervenção segundo níveis determinados, quais sejam: medidas de competência do governo federal; medidas envolvendo cooperação entre governo federal e governos estaduais; medidas de natureza legislativa e medidas de natureza institucional, estas pertinentes à implantação do Plano. R evelava-se, portanto, um nítido propósito de articular as iniciativas de competência do Executivo com as de competência do Legislativo. É também nítida a intenção de promover uma articulação entre governo federal e governos estaduais. $N$ essa medida, 0 governo $\mathrm{FHC}$ buscou enfrentar os limites e os constrangimentos impostos pelo pacto federativo, pelo menos nessa área de intervenção governa mental. D o mesmo modo, é flagrante o desejo de articular o PN SP com as políticas de controle ao tráfico de drogas e com o II PN DH (2002). A idéia, portanto, era superar o insulamento dessas políticas em territórios 
determinados, com suas agências e órgãos especializados que não se comunicavam entre si.

A lém dessa característica de estruturação, o PN SP foi organizado segundo procedimentos muito claros e objetivos. Em cada nível de intervenção governamental, as iniciativas organizavam-se segundo compromissos. C ada compromisso vinha associado ao elenco de ações a serem empreendidas, à descrição dos seus principais participantes e aos resultados esperados para o biênio 2000-2002. Essa forma de estruturação do Plano indicava igualmente um esforço para acompanhar a execução das medidas e para promover avaliação de seus resultados.

$Q$ uando às medidas de competência do governo federal, foram eleitos compromissos relacionados com o combate ao narcotráfico e ao crime organizado; desarmamento e controle de armas; repressão ao roubo de cargas e melhoria da segurança nas estradas; implantação do subsistema de inteligência de segurança pública; ampliação do Programa de Proteção a Testemunhas e Vítimas de C rime; e regulamentação da exposição da violência à mídia. Q uanto ao combate ao narcotráfico, as medidas compreendiam tanto operações sistemáticas de repressão, como melhoramento da vigilância nas fronteiras, portos e aeroportos; interdição de campos de pouso clandestinos; combate à lavagem de dinheiro; integra ção entre as polícias federal e rodoviária, entre as polícias militar e civil; amplo programa de reestruturação dos processos de seleção, recrutamento, treinamento, capacitação e reciclagem dos quadros policiais; criação do sistema prisional federal e de núcleos especiais de polícia marítima. Cuidou-se, por conseguinte, de redimensionar e melhor articular os diferentes órgãos e subsistemas especializados na contenção do narcotráfico, tanto assim que a lista de participantes alcançava a Secretaria N acional AntiD rogas, do Gabinete da Segurança Institucional; o M inistério da Justiça, por meio da Secretaria $\mathrm{N}$ acional de Segurança Pública, do D epartamento de Polícia Federal; o M inistério da Fazenda, por intermédio da R eceita Federal, do Conselho de Controle das A tividades Financeiras (CPAF) e do Banco $C$ entral; as secretarias estaduais da segurança e fazenda; as prefeituras; o poder Judiciário; o M inistério Público e sociedade civil organizada. Estranhamente, o compromisso prescindia de um parceiro tradicional na política de controle das drogas, qual seja, o M inistério da Saúde com suas iniciativas no sentido de restringir o consumo e oferecer sugestões para o tratamento. Esperava-se, com a implantação dessas medidas, a identificação e responsabilização dos principais traficantes que 
operavam no país; a redução da entrada de drogas ilícitas; a redução do contrabando; a redução das operações financeiras ilegais, além da melhoria dos controles institucionais, sobretudo os relacionados às fronteiras, como portos, aeroportos e aduanas. Tratava-se, portanto, de um propósito ousado, pois pretendia reverter inteiramente 0 modo de funcionamento tradicional das agências encarregadas de conter essa modalidade de crime organizado.

O utra iniciativa importante e polêmica alcançou o desarmamento e controle de armas. Esse compromisso contemplou recadastramento e fiscalização das empresas de segurança privada; proibição do comércio de armas de fogo para civis; cadastro nacional de armas apreendidas; intensificação do processo de implantação do Sistema $\mathrm{N}$ acional de Armas, criado ainda no primeiro mandato do presidente $\mathrm{FHC}$; campanhas de desarmamento e recolhimento de armas ilegais. A qui, igualmente, é extenso o leque de atores participantes, inclusive o M inistério do Trabalho (dadas as implicações de desemprego esperadas com a política de proibição do acesso às armas de fogos para civis), o M inistério das R elações Exteriores, 0 $M$ inistério da D efesa e o M inistério da Indústria e do Comércio. Com a implantação desse compromisso, esperava-se sancionar a lei de proibição do comércio civil de armas, melhor regulamentação do uso de armas de fogo por policiais, redução das armas em mãos de criminosos, além de campanhas para conscientização dos riscos do porte, sobretudo ilegal, de armas.

Também mereceram destaque compromissos relacionados com a repressão ao roubo de cargas e a criação de um subsistema de inteligência em segurança pública. N o primeiro caso, a par do propósito de intensificar operações repressivas e de patrulhamento das estradas, cuidou-se ainda do socorro às vítimas, de ampliar $\mathrm{O} C$ adastro $\mathrm{N}$ acional de Veículos A utomotores (R enavam) e a criação do Cadastro de Veículos R oubados, como também da reciclagem e do treinamento de policiais especial izados para 0 enfrentamento dessa modalidade de crime. Esperava-se, com isso, diminuir as ocorrências policiaise tornar mais eficiente o sistema de vigilância e de segurança para condutores de veículos de transporte de mercadorias. N o tocante ao subsistema de inteligência, previu-se a implantação do D ecreto no 3.448/00, que criou o Subsistema de Inteligência em Segurança Pública sob a coordenação da A gência Brasileira de Inteligência. Cogitou-se uma maior integração entre os serviços de inteligência federal e estaduais. D ada a natureza da questão, o Plano é mais econômico na listagem das iniciativas, é mais modesto na identificação do elenco de atores e agências 
participantes, e os resultados esperados limitaram- se a repetir o que estava previsto nas ações, como se as ações se transformassem, per si, em metas as serem al cançadas.

No que concerne às medidas envolvendo cooperação entre governo federal e governos estaduais, os compromissos contemplavam um leque bas tante variado de ações: redução da violência urbana; inibição de gangues e combate à desordem social; eliminação de chacinas e execuções sumárias; redução da violência rural; intensificação de ações previstas no II PN DH ; capacitação profissional e reaparelhamento das polícias; aperfeiçoamento do sistema penitenciário. A redução da violência urbana al cançava medidas operacionais tradicionais - como melhoria da vigilância e do patruIhamento e o cumprimento de mandatos de prisão - , mas também grupos especiais anti- seqüestros, guardas municipais e apoio comunitário às políticas de lei e ordem. Esperava- se a redução anual dos crimes contra a pessoa e demais modali dades delituosas, assim como a redução da insegurança nos bairros e 0 aumento da confiança nos policiais. No domínio da inibição das gangues e da desordem urbana, compareciam medidas como controle da venda de bebidas alcoólicas, criação de delegacias especializadas para 0 atendimento de adolescentes, inclusive serviços para acolhimento de adolescentes e jovens adultos em conflito com a lei e programas de apoio comunitário. Esse compromisso também buscava, se não avocar para si, participar de políticas de reforma urbana tendentes à recuperação do espaço público.

I gualmente, pretendeu criar forças especiais e integradas para combate e repressão aos grupos de extermínio, justiceiros e pistoleiros, inclusive punição rigorosa da violência policial, dadas as freqüentes denúncias de participação de agentes policiais naquelas organizações criminosas. Q uanto à violência rural, o Plano não economizou ações: consolidação do Sistema de Informações de Conflitos A grários e Tensões Sociais no C ampo (Sica); instalação de ouvidorias agrárias estaduais; acompanhamento de ações integratórias; constituição de equipes de prevenção de conflitos rurais; estruturação da Divisão de ConflitosA grários da Polícia Federal. Esse compromisso, por sua vez, reclamava a participação de outros atores e agências para além daqueles que tradicionalmente têm sob seu encargo a segurança pública, como o M inistério da R eforma Agrária, por meio do Instituto $\mathrm{N}$ acional de Colonização e R eforma Agrária (Incra) e da 0 uvidoriaA grária. Como resultados esperados, a par da redução dosconflitos agrários, sobretudo com desfechos fatais, visou-se à redução das 
armas no campo e à criação de forças especializadas no enfrentamento dessa modalidade de conflito social.

N o que concerne à interface com o II PN DH, o I PN SP listava um conjunto de ações variadas, relacionadas com prevenção da violência, serviço civil voluntário, redução do consumo de drogas e apoio à recuperação de dependentes, apoio às mulheres em situação de risco, a centros integrados de cidadania e ao Programa Bolsa Escola. N ão é preciso dizer que o rol de atores e agências convocados foi extenso. 0 sresultados espera dos compreendiam a redução dos riscos de envolvimento de adolescentese jovens adultos no consumo e tráfico de drogas, o maior envolvimento da sociedade civil organizada e de comunidades na redução do crime e da violência urbanas, além da erradicação do trabalho infantil.

Q uanto ao reaparelhamento das polícias, o Plano contemplava a cria ção do Fundo $\mathrm{N}$ acional de Segurança Pública - o que de fato foi realizado; a capacitação de policiais civis (federais e estaduais) e militares; 0 apoio à polícia comunitária; o programa de apoio a policiais e suas famílias; as ouvidorias estaduais e os mecanismos de controle externo; a execução de tarefas admini strativas por agentes não- policiais e o combate à impunidade.A lém das tradicionais agências de controle e repressão ao crime, foram convocados o M inistério do Planejamento, 0 rçamento e G estão; a C aixa Econômica Federal; 0 Instituto de R esseguros do Brasil; 0 Conselho $\mathrm{Na}$ cional de D esenvolvimento Científico eTecnológico (C N Pq); a Fundação C oordenação de A perfeiçoamento do Pessoal de N ível Superior (C apes); além de universidades, centros de pesquisa e organizações nãogovernamentais com experiência em treinamento, estudos e pesquisas da ação policial. Esperava-se, como principais resultados, a estruturação dos quadros policiais, uma mai or integração entre as polícias (em distintos níveis e segundo as distintas corporações), o reaparel hamento das organizações policiais, a redução de policiais vitimados em ação e o aumento da presença policial nas ruas. U ma leitura rápida desse compromisso e do conjunto de ações sugere claro aceno para contar com aquiescência e apoio das corporações policiais para o êxito do Plano. Se ele reconhece, em linhas gerais, que o mau desempenho dos agentes policiais e 0 mau funcionamento dasagências de controle social respondem em grande parte pela baixa eficiência das políticas de segurança, reconhece igualmente que policiais trabal ham sob condiçõesinadequadas, inclusive risco permanente de morte. $D$ aí porque 0 apelo às agências de financiamento (por exemplo, de condições especiais para o financiamento de habitação para 
policiais) e de financiamento de segurosem caso de acidentes e ocorrências de óbito. I gualmente interessante observar foi a convocação do C N Pq e da C apes, como também de universidades, centros de pesquisa e organizações da sociedade civil organizada capazes de colaborar na melhoria dos quadros policiais. 0 Plano reconhece que a produção de conhecimento, nessa área, é indispensável à reforma policial. R econhece ainda que o estoque de conhecimento acumulado, ainda que insuficiente, foi produzido fora dos quadros profissionais das agências de segurança. C onvém, portanto, importar esse conhecimento, tanto quanto estimular novos estudos fundados em metodologias científicas. Certamente, a convocação das agências de fomento ao conhecimento científico teve por meta a criação de programas de política induzida, algo que vem sendo desenvolvido com timidez no domínio das ciências sociais, inclusive as aplicadas.

Finalmente, tratamos do compromisso de aperfeiçoamento do sistema penitenciário. N esse domínio, houve pouca inovação. Insistiu-se em medidas tradicionais, como ampliação do sistema prisional estadual e federal, mutirões penitenciários, educação e profissionalização de detentos, capacitação de agentes penitenciários, assistência aos egressos, estímulo à aplicação de penas alternativas, além do aprimoramento do cumprimento da liberdade condicional e do regime aberto. 0 rol de atorese agências participantes contempla, a par da Secretaria $\mathrm{N}$ acional de Justiça, do C onselho de Política Penitenciária e da Secretaria de Estado dos D ireitosH umanos, D efensorias Públicas, sociedade civil organizada com atuação na área de assistência e aten dimento a presose organizações de egressospenitenciários. 0 s resultados esperados foram modestos: aumento de vagas; expansão da aplicação de penas alternativas; melhoria das condições de habitabilida de nas prisões; programas de reinserção social de egressos, mediante sua profissionalização. O bservamos, por conseguinte, que esse compromisso inovou pouco, exceto quanto à criação de um sistema federal penitenciário.

Q uanto ao aperfeiçoamento legislativo, as iniciativas governamentais não foram de pouca importância nem mesmo de pequena envergadura. As principais contemplam os projetos de mudança do Código Penal, do Processo Penal e da Lei de Execuções Penais. A demais, foram encaminhados projetosalterando a Lei de D rogas, propondo punição mais rigorosa para os crimes relacionados a contrabando, regulamentando a identificação criminal nacional, recrudescendo a punição para crimes de roubo e receptação de cargas, regulamentando a infiltração policial e os serviços de inteligência correlatos. 
Em nível institucional, os compromissos pretenderam potencializar a capacidade de implementação e monitoramento das ações previstas no I PN SP. Contemplaram ações como o Programa de Integração N acional de Informações de Justiça e Segurança Pública (Infoseg); 0 O bservatório $\mathrm{N}$ acional de Segurança Pública; 0 C omitê de A companhamento e Integração dos Programas Sociais; o C enso Penitenciário; a Construção de Base de $D$ ados para o A companhamento das Polícias e uma pesquisa nacional de vitimização.

Todas as iniciativas previstas no Plano foram acompanhadas de projetos de execução implementados pelos diferentes órgãos do M inistério da Justiça, por intermédio das secretarias de Estado dos Direitos $\mathrm{H}$ umanos, da Secretaria N acional de Segurança Pública, da Secretaria N acional de Justiça e do C onselho Penitenciário. Ao aproximar-se do final do mandato, o governo promoveu uma espécie de balanço do Plano, em especial de seu andamento e dos resultados esperados em curto prazo. 0 balanço indicava o privilégio conferido a algumas ações em detrimento de outras. A lgumas pareceram mais exeqüíveis de imediato, enquanto outras envolviam maior empenho governamental no sentido de convencer seus opositores, amainar as críticas e reservas e possibilitar avanços na área. A ções de competência do governo federal andaram com maior fluência, ainda que seus resultados não tenham sido logrados até o final do segundo mandato de FH C. A quelas que envolveram cooperação com os governos estaduais encontraram maior dificuldade, muitas sequer saíram do papel. Em outras palavras, a despeito da confortável situação político-institucional conquistada pelo governo $\mathrm{FHC}$ com a reeleição, a área de segurança pública continuou enfrentando os mesmos constrangimentos políticos herdados do mandato anterior.

É certo que houve méritos flagrantes. Talvez, o mais importante seja que, pela primeira vez na história republicana, o governo federal avocou a coordenação da política de segurança, formulando uma política nacional com diretrizes claras e definidas, com propósitos de articulação inter e intra institucional com amplo e extenso alcance, de sorte a articular problemasdistintos, mas que se apresentavam ao governo federal como implicadosentre si. C uidou também de reunir, no Plano, os diferentes pontos de vista que expressavam diferentes concepções sobre o modo como devem ser asseguradas, no país, lei e ordem. Em especial, buscou conciliar e estabelecer pontos de negociação entre ativistas de direitos humanos, profissionais especializados e representantes de corporações, sobretudo as poli- 
ciais. Em particular, evitou confrontar-se com tais corporações. 0 Plano não apenas reconhecia méritos nas demandas por lei e ordem nascidas dos agentes e das agências policiais, como também considerava politicamente estratégico contar com o apoio, senão de todas as corporações policiais, pelo menos de suas lideranças capazes de influenciar seus subordinados. É notório também o efforço por inovação, por afastar-se das fórmulas tradicionais que insistem, tão somente, no reaparel hamento dos quadros policiais. $N$ essa medida, o Plano enfocava a aliança entre conhecimento, formação profissional especializada e intervenção competente. A o fazê- $\mid 0,0$ governo cuidou de articular, de modo orgânico, as relações entre diagnóstico, planejamento, execução de ações e avaliação, cobrando resultados e realizando balanço de conquistas e fracassos.

Se os méritos não são poucos e sequer de pequeno impacto, por que então o I PN SP sofreu tantas críticas e se mostrou, após o primeiro ano de sua execução, desgastado? Logo na apresentação do Plano, vieram críticas procedentes de distintos setores: mídia, profissionais especializados, pesquisadores e corporações profissionais. Enquanto alguns profissionais e pesquisadores acordaram com o tom geral do PN SP, produzindo críticas e ponderações pontuais, a mídia e as corporações profissionais puseram sob suspeição, desde logo, o seu alcance e a capacidade do governo federal de implementar os compromissos e as ações propostas. U m sumá rio do inventário dessas críticas repousa na desconfiança para com um Pla no tão abrangente que lhes parecia não dispor de foco definido porque não conferia prioridade aos compromissos. Para alguns, a prioridade continua va no reaparelhamento policial: ampliação dos quadros, melhores salários e condições de trabalho e, inclusive, maior liberdade de ação para osagentes policiais. I ronizavam-se, com freqüência, algumas iniciativas, sobretudo as relacionadas com reforma urbana e iluminação. Jocosamente afirmavam que o problema de segurança era, para o governo federal, um problema exclusivamente de iluminação pública e de melhoria do espaço urbano, ressuscitando a velha crítica da direita contra as medidas de justiça distributiva no combate ao crime e à violência. I gualmente, foram fortes as críticas contra a política de desarmamento e as suspeitas de que o crime organizado, especialmente o narcotráfico não seria efetivamente atingido, já que o Plano pouco dizia a respeito de como atacar a corrupção e o envolvimento de políticos e empresários com o tráfico de drogas.

U $m$ ano após a execução do PN SP parecia que nada havia sido implementado. C omeçaram a aparecer, aqui e acolá, na mídia, críticas mais subs- 
tantivas, as quaisinclusive falavam em salvar o Plano, já que, em sua origem, propósitose concepção, o caminho parecia certo, pelo menos para aqueles para quem segurança pública deveria ser entendida no contexto mais amplo de proteção dos direitos humanos. Indicado para ocupar a embaixada do B rasil em Portugal, o ministro Gregori foi substituído por José $C$ arlos Dias, advogado notório, defensor de presos políticos, ex-secretário da Justiça do governo do estado de São Paulo, na gestão Franco M ontoro, profundamente identificado com as lutas pela reconstrução da normalidade democrática. 0 novo ministro resolveu dar impulso ao PN SP, promovendo ajustese a introdução de pequenas reformas com o propósito de amainar críticas e resistências, bem como acelerar a implementação de medidas. Corrigiu excessos e ampliou medidas que Ihe pareciam de maior possibilidade de implementação. Sua passagem pelo M inistério não foi longa, gerou inúmeros conflitos por conta do estilo de sua condução e resultou em sua demissão. A pós uma curta passagem do deputado federal Aloysio $\mathrm{N}$ unes Ferreira - em cuja gestão ocorreram as mortes dos prefeitos de C ampinas e de Santo André - , foi indicado, para titular do M inistério da Justiça, outro notório advogado criminal, professor titular de direito penal da tradicional Faculdade de Direito da U SP, M iguel R eale Júnior. R eale cuidou igualmente de fazer prosperar o Plano e, principalmente, acelerar a votação dos projetos de reforma do Código Penal (do qual havia sido presidente da Comissão de R eforma), do Código Processual Penal e da Lei de Execuções Penais. $\mathrm{N}$ o final do segundo mandato, o ministro entrou em confronto com o presidente $\mathrm{FHC}$ em virtude de desentendimentos quanto à intervenção federal no estado do Espírito Santo, proposta pelo M inistério da Justiça, diante de graves problemas de corrupção e da presença de grupos de execução sumária com larga influência no aparelho governamental estadual. Contrariado pelo fato de o governo avaliar a inoportunidade da medida diante da proximidade das eleições, M iguel R eale pediu demissão, tendo sido substituído por seu chefe de Gabinete, Paulo de Tarso $R$ amos $R$ ibeiro.

A seqüência de conflitos político-institucionais alterou o ritmo e a agenda das mudanças pretendidas pelo Plano, que contrariava interesses incrustados há muito na burocracia civil e militar do governo federal. $\mathrm{M}$ ais do que isso, revelava com maior intensidade a face do governo $\mathrm{FHC}$ para a área de segurança pública: elevada capacidade de formulação de políticas, baixa capacidade de implementação. D e fato, dado o escopo de mudanças, sua implementação não poderia ter sido relegada à liderança 
de um M inistério politicamente cada vez mais enfraquecido, sem diálogo efetivo com lideranças parlamentares e com a presença discreta na mídia e na formulação da agenda política nacional, em especial em período eleitoral. Teria sido necessário maior empenho da presidência da R epública no sentido de tornar a questão da segurança pública um investimento politicamente conseqüente. D e modo geral, o trâmite das medidas ficou ao encargo dos gabinetes executivos, cuja estrutura administrativa é freqüentemente precária, a despeito da existência de abnegados funcioná rios identificados com os negócios públicos e com a direção impressa às políticas públicas. Tudo o que dependeu de negociação política acabou sendo relegado em face das preocupações primordiais de final de mandato de FHC , como manter o controle da economia depois do trauma da desvalorização monetária com suas conseqüências sobre o controle infla cionário e sobre o ritmo das políticas de desenvolvimento industrial, tecnológico, entre outras políticas, a par, é claro, de seus notórios efeitos sobre o quadro político-partidário e sobre o cenário eleitoral premente. A demais, uma sucessão de conflitos no interior do poder Legislativo, com a renúncia de mandato de dois caciques políticos eleitorais - Antonio C arlos M agalhães (PFL da Bahia) e Jarbas B arbalho (PM D B do Pará) - , além do senador José R oberto Arruda (DF), líder do governo federal, contribuiu para eclipsar ainda mais a política de segurança pública. Por um lado, as iniciativas governamentais nessa área deixaram de comparecer com maior freqüência no noticiário nacional; em contrapartida, o crime violento continuou ganhando espaço. N esse contexto, o I PN SP, muito mais visado do que o II Programa $\mathrm{N}$ acional de Direitos H umanos, permaneceu low profile, não se constituindo em matéria de negociação política.

\section{Controle do tráfico de drogas ${ }^{15}$}

Certamente, a política de controle do tráfico e consumo de drogas faz, ou deveria fazer, parte das políticas de segurança formuladas e implementadas pela Secretaria N acional de Segurança. N o entanto, desde sua cria ção, aquela política mereceu um tratamento diferenciado, dadas suas conexões com segurança pública, segurança nacional, saúde pública e educação. 0 governo FHC não alterou, em linhas gerais, esse enfoque, ainda que essa política estivesse, no início do primeiro mandato, afeta diretamente ao M inistério da Justiça. Ao longo de seu governo, contudo, é flagrante a transferência de competência da esfera da segurança pública
15. Emboracom novas informações, esta análise resume, em parte, texto mais extenso e analítico originalmente publicado em Adorno e Pedroso (2002). 
para a esfera da segurança do Estado nacional. À medida que essa tendência foi se consolidando, por uma série de iniciativas, essa política foi tornando-se mais e mais independente do M inistério da Justiça e progressivamente afastada do controle da Polícia Federal.

A legislação brasileira de controle do tráfico internacional e local de drogas bem como do uso ilícito teve início em novembro de 1938. D esde sua criação e até recentemente, essa legislação parece ter sido influenciada por três fontes de pressão: a) legislação das $\mathrm{N}$ ações U nidas (O N U ); b) tendências da política norte-americana de combate ao tráfico internacional (que inclusive influenciaram a celebração de inúmeros acordos internacionais, inicialmente com países- fronteiras naA mérica do Sul e, posteriormente, com a América do N orte, a Europa - Portugal e Itália - e África); c) crescimento da criminalidade urbana violenta, em especial estimulada pelo crime organizado, mais propriamente pelo narcotráfico.

$\mathrm{N}$ a história dessa legislação é possível identificar três momentos distintos. 0 primeiro, com início no final da década de 1940 e encerrado em outubro de 1976, nasceu, ao que tudo indica, do influxo das orientações normativas internacionais: a C onvenção Ú nica sobre Estupefacientes, assinada em N ovaYork, em 30 de março de 1936, e a Convenção para R epressão do T ráfico Ilícito de D rogas N ocivas, assinado em Genebra, em 26 de junho do mesmo ano. $N$ esse período, a legislação brasileira evoluiu muito lentamente. Basta verificar que a C onvenção Ú nica so bre Estupefacientes somente foi ratificada e promulgada em 27 de agosto de 1964 (D ecreto no 54.216), portanto 28 anos após sua celebração! 0 segundo período teve início com uma legislação mais abrangente e ousada: a Lei no 6.368, de 26 de outubro de 1976. C ertamente, ela também respondeu a um influxo externo representado pela C onvenção sobre Substâncias Psicotrópicas, assinada em Viena, em 21 de fevereiro de 1971, bem como um novo Protocolo das Emendas à Convenção Ú nica sobre Estupefacientes, assinada em G enebra, em 25 de março de 1972.

0 terceiro período teve início com a criação da Secretaria $\mathrm{N}$ acional de Estupefacientes por meio da Lei № 8.764, de 20 de dezembro de 1993, com a qual se deu a consolidação da política nacional de controle do uso abusivo e do tráfico ilícito de drogas. Contudo, persiste a tendência, notada no período anterior, de consolidar o Sistema $\mathrm{N}$ acional de Prevenção, Fiscalização e R epressão de Estupefacientes, articulando e aprofundando os vínculos entre programas e planos, agentes e agências. $\mathrm{N}$ a mesma direção, esse sistema nacional persistiu centralizando o controle dos múltiplos as- 
pectos relacionados à política para o setor: controle da produção e da comercialização de substâncias, inclusive com fins farmacêuticos e medica mentosos, repressão do tráfico ilícito nacional e internacional, inclusive em suas conexões com outras modalidades de crimes (contrabando de armas, seqüestros, lavagem de dinheiro etc.); tratamento e recuperação de dependentes; difusão de informações de interesse público, inclusive produção de informações de caráter científico, e controle da circulação de informaç̧ões de interesse sigiloso; educação de cidadãos comuns, inclusive no tocante à formação de opiniões desfavoráveis ao uso abusivo e ao tráfico ilícito de drogas, bem como programas de formação de pessoal especializado.

D urante o governo $\mathrm{FHC}$, essa tendência foi aprofundada: 0 sistema cresceu, tornou-se bem mais complexo (em relação a seu perfil no período anterior) e adquiriu uma autonomia provavelmente antes desconhecida. Fato significativo nesse processo foi sua transferência, não sem conflito, do eixo de controle do $M$ inistério da Justiça (com o conseqüente esvaziamento do C onselho Federal de Entorpecentes- C onfen) para a C asa M ilitar da Presidência da R epública, tornando-se a matéria - drogas e seu controle - objeto de interesse cada vez mais próximo das maisal tas instâncias de poder decisório, principal mente da presidência da R epública.

À medida que o problema da segurança foi se tornando maise maisum problema com maior peso na agenda governamental, o tráfico internacional passou ser visto como uma questão delicada. As preocupações gravita vam não apenas em torno dos desarranjos que o tráfico internacional provoca no tecido social, com o conseqüente aumento da criminalidade comum, em especial o crime violento, mas também em torno de suas implicações políticas mais complexas: corrupção de autoridades, sobretudo quanto ao controle de fronteiras com suas inconvenientes conseqüências sobre a soberania do Estado-nação; lavagem de dinhei ro e outros crimes conexos com o sistema financeiro. Assim, um dos alvos atuais das políticas de controle de drogas tem sido o de retirar o controle do tráfico internacional da esfera da polícia civil (polícia federal). Esse alvo tornouse, portanto, imperativo, até porque as forças policiais federais disponíveis não apenas pareciam insuficientes para conter problema de tal magnitude, como também podiam estar eventualmente envolvidas no tráfico.

$\mathrm{N}$ essa mesma linha de orientação, não é estranho todo o esforço empreendido por ampliar os acordos internacionais, como o estabelecido com a R epública Italiana, que é paradigmático: não somente é - ou parece sê-lo - o mais completo em termos de atividades previstas, inclusive por- 
que é mais explícito no tocante ao intercâmbio de informações "criminais" (identidade de traficantes, conexões internacionais, modalidades de ação etc.) e às iniciativas bilaterais no campo penal (prevendo-se expulsão de estrangeiros e troca de prisioneiros), mas também arma todo um sistema de redes (redes de informação e de intercâmbio) constituídas na esteira do modelo instituído do tráfico internacional.

Pela primeira vez, uma iniciativa governamental (Lei no 9.017/ 95, de 30 de março, regulamentada pelo D ecreto o 1.646/95, de 26 de setembro) procura estabelecer controle e fiscalização sobre substâncias que possam vir a ser utilizadas na fabricação da cocaína. A legislação estabelece um rigoroso controle sobre as empresas, submetendo- as à fiscalização do D epartamento de Polícia Federal, a quem cabe expedir licenças de funcionamento.

O utra importante iniciativa nessa área diz respeito à Lei no 9.034/95, de 3 de maio, de repressão ao crime organizado. Embora se trate de um documento legislativo bastante controvertido, essa iniciativa procurou ca tegorizar penalmente o crime organizado e estabelecer as formas possíveis de sua punição. Inicialmente 0 texto legal optou por uma definição genérica de crime organizado: o legislador evitou caracterizações penais muito precisas, de forma a facultar ao poder público, especialmente no que concerne às suas funções repressivas, a possibilidade de conferir maior flexibilidade às estratégias de repressão ao crime organizado. Q uase três anos mais tarde, partilhando essa mesma orientação, procurou- se conter 0 "branqueamento" ou a"lavagem" de dinheiro com a Lei no 9.613/98, de 3 de março. Por força desta lei, constitui crime ocultar ou dissimular a natureza, a origem, a localização, a disposição, a movimentação ou a propriedade de bens, os direitos ou os valores provenientes, direta ou indiretamente, de tráfico de drogas, de contrabando ou tráfico de armas, de atividade praticada por organização criminosa.

Essa legislação objetivou não apenas qualificar a natureza de tais operações, precisando-as do ponto de vista jurídico, mas procurou também estabelecer normas processuais especiais com vistas a evitar fugas freqüentemente patrocinadas por uma legislação penal defeituosa. É significativo também que ela tenha responsabilizado as instituições financeiras pela manutenção de registros, identificação de clientes e comunicação às autoridades competentes de toda e qualquer movimentação ou operação que ultrapasse limites determinados por órgão regulador das atividades financeiras. Essa mesma lei criou o Conselho de Controle das A tividades Fi- 
nanceiras (C oaf), subordinado ao M inistério da Fazenda, com a finalidade de examinar e oferecer um encaminhamento administrativo a todas as ocorrências suspeitas de operações ilícitas. Com base nessa iniciativa, a política nacional de controle e repressão ao tráfico internacional de drogas estende seu raio de ação para o âmbito do M inistério da Fazenda, adensando ainda mais o network constituído.

A transferência de eixo da effera da justiça para a effera militar consolidou- se com a edição do D ecreto no 2.632/ 99, de 19 de junho, que modificou o Sistema $N$ acional de Prevenção, Fiscalização e R epressão de Estupefacientes em Sistema $\mathrm{N}$ acional Antidrogas. Ao lado das atribuições anteriores, ampliou-se o elenco de competências para contemplar outras iniciativas como a faculdade de propor reformas institucionais e a modernização organizacional e técnico-operativa, como firmar convêniose contratos com instituições, estimulando a realização de estudos e pesquisas.

Esse decreto criou a Secretaria $\mathrm{N}$ acional A ntidrogas, subordinada à $\mathrm{C}$ asa M ilitar da Presidência da R epública, para a qual foi indicado o doutor Walter F. M aierovich, juiz de direito, conhecido por sua atuação na área; institui também o C onselho $\mathrm{N}$ acional A ntidrogas (C onad), órgão consultivo superior do C hefe da C asa M ilitar da Presidência da R epública. Esse conselho tem por competência aprovar a Política N acional Antidrogas, exercer orientação normativa nessa matéria, inclusive no que respeita à recuperação de consumidores, além de acompanhar e avaliar a gestão dos recursos do Fundo $\mathrm{N}$ acional Antidrogas (Funad), denominação nova para 0 antigo Fundo de Prevenção, R ecuperação e de Combate às $D$ rogas de A buso (Funcab). A composição do $C$ onad obedeceu às mesmas diretrizes do antigo Confen - órgão que se encontrava subordinado ao M inistério da Justiça - , incluindo, além de dois representantes das Forças A rmadas, um representante do órgão de inteligência do governo federal. É importante ressaltar que o mesmo decreto extinguiu o antigo D epartamento de Estupefacientes na Polícia Federal, órgão também subordinado ao M inistério da Justiça.

Essa terceira fase vem sendo caracterizada não somente pelo aperfeiçoamento do network de atores e agências encarregadas de pôr em funcionamento o sistema nacional de controle e repressão ao tráfico de drogas, como também - o que parece mais significativo - a transferência de sua coordenação da esfera do M inistério da Justiça, com o conseqüente esvaziamento das atribuições conferidas à polícia federal nessa matéria, para a esfera militar. A questão do controle passou a ser um problema de 
segurança nacional, envolvendo não apenas o controle interno da ordem civil, mas, sobretudo, o controle das fronteiras nacionais, daí a tendência de sua militarização.

Por um lado, a complexidade que a questão foi adquirindo tendeu a tornar as agências e as instâncias coordenadoras entidades dotadas de autonomia, inclusive para propor a celebração de convênios entre estados da federação. A ssim, acabam por se transfigurar em centrosnormativos, dotados de juridicidade própria, um pouco às expensas do monopólio estatal da produção normativa. Por outro lado, à medida que a questão ascende à proximidade dos centros decisórios, as políticas e as orientações que vão sendo delineadas parecem favorecer a centralização do poder do governo federal. Tudo indica, por conseguinte, dois movimentos com direções distintas. U m centrífugo - que tende a desenvolver-se nos labirintos da maIha estatal - e outro centrípeto, que, por sua vez, se concentra em torno das principais instâncias decisórias.

\section{Conclusão}

É certo que o governo $\mathrm{FHC}$ não deixou sua marca no domínio da segurança pública.Todavia, não há como deixar de reconhecer avanços no campo dos direitos humanos e mesmo no da segurança pública. 0 novo governo federal, eleito para o quadriênio 2003-2006, formulou uma política que guardava profundas inspirações no Plano de governo de FHC, em seu segundo mandato. Em particular, as bases da política de direitos humanos foram todas consolidadas pelo governo anterior. $\mathrm{N}$ ão há, nesse domínio, grandes inovações. D o mesmo modo, a implementação das políticas de direitos humanos e de segurança pública, em curso, não encontrou um território arrasado, como se nada houvesse sido feito ou tivesse havido uma espécie de regressão institucional e administrativa. É evidente que a nova gestão se apóia em larga medida na experiência acumulada e aproveita-se mesmo do lastro de funcionários e consultores remanescentes do governo $\mathrm{FHC}$ ou que haviam colaborado na formulação quer dos Programas $\mathrm{N}$ acionais de Direitos $\mathrm{H}$ umanos, quer do Plano $\mathrm{N}$ acional de Segurança Pública.

Há também que se reconhecer que, em uma área como a de segurança, justiça e direitos humanos, em que problemas crônicos vieram se acumulando há décadas, contribuindo assim para enraizar hábitos e atitudes de como tratar questões de lei e ordem, não era de se esperar que resulta 
dos pal páveis e visíveis fossem conquistados em curto espaço de tempo. É bastante provável que algumas conquistas somente possam merecer ava liação objetiva, isenta das influências da análise conjuntural, daqui a al guns anos, digamos no espaço de uma geração, quando esforços empreendidos para a mudança institucional tenham apresentado seus sinais.

Em curto prazo, contudo, cabe dizer que o esforço governamental não logrou romper com os problemas herdados do primeiro mandato. $\mathrm{N}$ ão se logrou efetivamente articular e integrar as políticas de direitos humanos, segurança pública e controle e tráfico de drogas. C ada uma dessas políticas continuou operando segundo lógicas próprias, locais e setoriais, atendendo às demandas dos diferentes grupos de pressão que haviam, desde há muito, se posicionado no interior das agências encarregadas de implementar tais políticas. Com isso, permaneceu 0 gap entre direitos humanos e segurança pública; não se construíram as bases para lograr um consenso político de como implementar lei e ordem sem comprometer o Estado de D ireito e as políticas de proteção dos direitos humanos. Tanto direitos humanos como segurança pública transformaram-se em matéria presente na agenda política nacional. Contudo, 0 diálogo entre os três poderes nessa matéria - em especial, entre o Executivo e o Judiciário - mantiveram-se como estava há, pelo menos, uma década. A classe política continuou manifestando interesse apenas pontual por tais questões, quando muito mobilizando interesses corporativos, interesses de mercado ou as tradicionais demandas dos ativistas em direitos humanos. As resistências restaram fortes e atuantes, contra as quais o governo federal agiu com pouco interesse e eficiência. 0 final do mandato deixava evidente que as promessas não haviam sido cumpridas, o Plano geral havia falhado, novos problemas emergiam sem que houvesse efetiva disposição do Executivo em enfrentá-los com tenacidade. N ão é estranho que, apesar de a C omissão Parlamentar de Inquérito para investigar o $\mathrm{N}$ arcotráfico no B rasil, instalada na $\mathrm{C}$ âmara dos D eputados, ter identificado redes envolvendo políticos profissionais, empresários, profissionais liberais, autoridades dos três poderes, inclusive nomeando responsáveis pelos crimes de tráfico de drogas, corrupção, lavagem de dinheiro etc., o governo federal nada tenha recolhido dos resultados alcançados e pouco tenha se esmerado para apurar responsabilidades e punir seus autores. 


\section{Referências Bibliográficas}

Adorno, S. (1999), "Insegurança versus D ireitos H umanos: entre a lei e a ordem". Tempo Sodial, 11(2): 129-153, out., São Paulo.

Ad o R N O, S. \& C AR DIA, N . (2002), “V iolência, crime e insegurança: há saídas possíveis?" In: . L ivroV erde: desafios para a gestão da região metropolitana deC ampinas. C ampinas, Instituto de Economia da U niversidade Estadual de $\mathrm{C}$ ampinas. Ador no, S. \& Pedroso , J. (2002), " Políticas de controle e repressão ao tráfico internacional de drogas: estudo comparativo de Brasil e Portugal (1980-1990)". In: Pureza, José M anuel \& Ferreira, Antonio C. (orgs.). A teia global: movimentos sodiais e institui ções, Porto, Afrontamento, vol. 7.

AN DR ADE, F. C. D. (1997), N íveis e padrões de mobilidade social em anco regiões metropolitanas. Dissertação de mestrado, B elo H orizonte, C entro de D esenvolvimento e Planejamento Regional (C edeplar) da U niversidade Federal de M inas Gerais (UFM G).

B R AsIL. C âmara Federal dos D eputados. (2002), "R elatório da C omissão Parlamentar de Inquérito destinada a investigar o avanço e a impunidade do narcotráfico". Braślia, Câmara Federal dos Deputados, nov. (relator: deputado M oroni Torgan).

B R A SIL. M inistério da Justiça, Secretaria N acional de Segurança Pública. (2000), "Plano N acional de Segurança Pública”. B raślia, disponível em w ww.unodoc.org/ brazil/ publicacoes/ nacional.

Br ASIL. M inistério da Saúde, (1991-2000), D atasus .

B R ASIL. Secretaria de Estado dos Direitos H umanos - SED H . (2002), D ireitos H umanos, 1995-2002: políticas públicas de promoção e proteção. B rasília, SED H , di sponível em www.mj.sedh.gov.br.

Brasil. Secretaria N acional de Segurança Pública - Senasp. (s. d.), disponível em www.mj.senasp.gov.br.

C AR DIA, N . (1999), A titudes, normas culturais e valores em relação à violência em dez capitais brasileiras. Braślia, M inistério da Justiça, Secretaria $\mathrm{N}$ acional de D ireitosH umanos. C AR DIA, N . et al. (2003), "H omicide rates and human rights violations in Sao Paulo: B razil: 1990 to 2002". H ealth and H uman R ights - A n International Journal, 6 (2): 15-33, $\mathrm{H}$ arvard School of Public Health.

C AR D o so, Fernando H enrique. (1994), M ãos à obra B rasil: proposta de governo. Brasília, [s. ed.].

Cerqueira, D. \& Lo bão,W. (2003), “D eterminantes da criminalidade: uma resenha dos modelos teóricos e resultados empíricos". Texto para discussão, 956, jun., R io de Janeiro, I pea. 
. (2003), "C ondicionantes sociais, poder de polícia e o setor da produção criminal". Texto para discussão, n. 957, jun., R io de Janeiro, I pea.

. (2003), “C riminalidade: social versus polícia”. Texto para discussão, n. 958, jun.,

$R$ io de Janeiro, Ipea.

Folha de S. Paulo. (1999-2002), Folha 0 nline [várias notícias], disponível em www1.folha.uol.com.br.

Godor, M. (2002), "Direitos humanos e violência". In: Lamounier, Bolívar \& FigueIR EDo, R ubens (orgs.). A era F H C, um balanço, São Paulo, Cultura, Editores Associados.

H AdDAD, E. et al. (2003), Justiça e segurança na periferia de São Paulo. os centros de integração de idadania. São Paulo, IBC crim.

Instituto Brasileiro de Geografia e Estatística - Ibge. Diretoria de Pesquisas, D epartamento de População e Indicadores Sociais. (1999), M ortes violentas: um panorama dos homiádios no Brasil. $R$ io de Janeiro, IBGE (mimeo.).

LEM GRUBER, J. et al. (2003), Q uem vigia os vigias? U m estudo sobre o controle externo no $B$ rasil. $R$ io de Janeiro, $R$ ecord.

M ello Jor ge, M. H. P. (1997), "Análise dos dados de mortalidade". R evista Saúde Pública, 31 (4): 5-25.

M EN D O ÇA, M . J. C . de et al. (2003), "C riminalidade e desigual dade social no Brasil”. Texto para D iscussão, 967 , jul. $R$ io de Janeiro, I pea.

Mesquita Neto, P. (2001), "Crime, violência e incerteza política no Brasil”. In: . V iolência no cotidiano, São Paulo, Fundação Konrad A denauer.

M esquita N eto, P. et al. (2002), "II R elatório N acional sobre Direitos H umanos no Brasil". São Paulo, C omissão Teotônio Vilela (CTV).

Organização M undial de Saúde - O ms. (2002), "R elatório M undial sobre Saúde eV iolência". W HO, G enebra (Etienne Krug et al. [eds.]).

O Estad O DE S.PAuLO . (1999-2002), [váriasnotícias], disponível em www.Estadão.com.br. Panamerican Health Organization - Paho. (s. d.), disponível em www.paho.org. Per ES, M . F.T. (2003), “Firearm impact in Brazilian violence: considerations for the development of violence prevention programs". R elatório de pesquisa, parte do projeto "Small A rms Survey Initiative", patrocinado pela O rganização M undial de Saúde.

Pero,V. (2003), “"M obilidade social no R io de Janeiro" . R io Estudos. R io de Janeiro, Prefeitura M unicipal do R io de Janeiro, fev. (coleção Estudos da Cidade).

PIn heiro, P. S. (1999), "I R elatório N acional sobre osD ireitosH umanosno Brasil”. São Paulo, U SP/ Secretaria de Estado dos Direitos H umanos.

Zaluar, A. (1999), "Violência e crime". In: M ICElı, Sergio (org.). 0 que ler nas dências sociais brasileiras, São Paulo, Sumaré, vol.1, pp. 13-107. 


\section{Resumo}

Este artigo dá continuidade a um ensaio anterior (A dorno, 1999) sobre as atividades governamentais do primeiro mandato do presidente Fernando $\mathrm{H}$ enrique $\mathrm{C}$ ardoso. Seu propósito é analisar a política de segurança pública formulada e implementada pelo governo em sua segunda gestão (1999-2002). A partir de uma síntese das principais conclusões, este ensaio explora o alcance das iniciativas introduzidas em três domínios: direitos humanos, controle do tráfico internacional de drogas e controle social - com destaque para o II Programa $\mathrm{N}$ acional de Direitos H umanos, o I Plano $\mathrm{N}$ acional de Segurança Pública e as políticas de controle do tráfico de drogas -, procurando concentrar sua atenção nas mudançasocorridas na conduta dos agentese das agências governamentais em relação ao mandato anterior. Tal como no estudo anterior, a análise procura inventariar al guns dos constrangimentos políticos que limitaram 0 alcance e 0 escopo das diretrizes formuladas e implementadas. Palavras-chaves: C rime; $V$ iolência; $M$ edo; Insegurança; C riminalidade; Políticas públicas de segurança; Direitos humanos; G overno FH C.

\section{Abstract}

This paper is a follow up of a previous article (A dorno, 1999) on the governmental activities of president Fernando $\mathrm{H}$ enrique C ardoso's first term of office. The idea here is to analyze the public safety policy that was created and implemented by the government during his second term (1999-2002). Based on a summary of the main conclusions, this study looks at how far-reaching were the initiatives introduced in three domains: human rights, international drug traffic control and social control highlighting the $2 \mathrm{nd} \mathrm{N}$ ational Program of $\mathrm{H}$ uman $\mathrm{R}$ ights, the 1 st $\mathrm{N}$ ational Program of Public Safety, and the policies for drug traffic control. A close look wastaken at the changes that occurred in the way the agents and the governmental agencies acted

Sérgio Adorno é professor associado do Departamento de Sociologia da Faculdade de Filosofia, Letrase Ciências H umanas da U niversidade de São Paulo e coordenador do $\mathrm{N}$ úcleo de Estudos da Violência/ Centro de Pesquisa, Inovação e Difusão daU niversidade de São Paulo. comparatively to the previous mandate. As in the first study, an inventory is made of some of the political constraints that limited the reach and scope of the formulated and implemented norms.

Key words: C rime; V iolence; Fear; I nsecurity; C riminality; Public safety policies; $\mathrm{H}$ uman rights; $\mathrm{FHC}$ government. 